\title{
Scenario-based modelling of the potential for solar energy charging of electric vehicles in two Scandinavian cities
}

\author{
Clara Good $^{a} *$, Mahmoud Shepero ${ }^{b}$, Joakim Munkhammar ${ }^{b}$, Tobias Boström ${ }^{a}$ \\ ${ }^{a}$ UiT The Arctic University of Norway, Department of Physics and Technology, Postboks 6050 \\ Langnes, N-9037 Troms $\phi$, Norway \\ ${ }^{b}$ Uppsala University, Department of Engineering Science, Uppsala University, P.O. Box 534, SE-751 \\ 21, Uppsala, Sweden \\ *Corresponding author (clara.good@uit.no)
}

\begin{abstract}
In order to contribute to the reduction of greenhouse gas emissions, electric vehicles (EVs) should be charged using electricity from renewable energy sources. This paper describes a study of photovoltaics (PV) utilization for EV charging in two Scandinavian cities: Troms $\varnothing$ in Norway and Uppsala in Sweden, with the objective to evaluate self-sufficiency and self-consumption.

The suitable areas for PV were determined using building area statistics and utilization factors. The PV yield was simulated for integration scenarios of 10\%-100\% of the suitable area. EV charging patterns were generated using a stochastic model based on travel survey data. The scenarios include EV penetration of $10 \%-100 \%$ of the personal vehicle fleet.

The results show that the PV energy yield could cover the EV load in most of the scenarios, but that the temporal load match could be improved. The energy balance was positive for all seasons and EV levels if the PV integration was over 50\%. The highest self-sufficiency was achieved in Troms $\varnothing$ during summer, due to the longer days. For high EV penetration and low PV integration, the self-sufficiency was higher in Uppsala, indicating that installed PV power is more important than yield profile above a certain number of EVs.
\end{abstract}

Keywords: electric vehicle charging, solar potential, self-sufficiency, self-consumption

\section{Introduction}

In the recent years, the awareness of the impacts of climate change has increased, and the need to reduce the emissions of greenhouse gases globally is evident. The introduction of electric vehicles $(\mathrm{EVs})^{1}$ in the transport sector has the potential to contribute significantly to reduced emissions of both greenhouse gases and harmful particles, provided that EVs are charged with electricity from renewable energy sources (RES) [1,2].

\footnotetext{
${ }^{1}$ Abbreviations: EV - Electric vehicle, BEV - Battery electric vehicle, PHEV - Plug-in hybrid electric vehicles, GIS - Geographical information system, LiDAR - Light detection and ranging, PV - photovoltaics, RES - Renewable energy sources, SOC - State of charge
} 
This is a postprint version of the final paper, which is accepted for publication in Energy: https://doi.org/10.1016/j.energy.2018.11.050

Incorporating renewable energy sources (RES) in the electricity grid has been extensively studied [3]. For example, Olauson, et al. [4] showed that the long and short-term variabilities resulting from shifting to RES in the Nordic countries will not change from today's variability. The authors argued that with hydropower balancing, a fossil and nuclear power independency can be achieved in the Nordic region.

There are many ways to model EV charging, where stochastic modelling was found to provide a better assessment of the system risks and deterministic models a better representation of worst case scenarios [5]. Refs. [6-9] relied on Markov chains to model the charging load of EVs. In [7], the authors used driving and parking states. In [6], an extended implementation where numerous driving states were employed. In [8], the authors decided to categorize the parking into three categories: work, home, other. Moreover, the authors alleviated the driving states from their model. In a recent paper [9], the authors used a Markov chain Monte Carlo model to study the impacts of uncontrolled charging on a local single phase distribution grid with 17 customers. The network was able to support at most $20 \%$ EV penetration level. In [10], the impact of EVs charging on the transformer of a residential grid was studied. The author showed that at $6.6 \mathrm{~kW}$ and $100 \%$ penetration, the transformer will operate $9.4 \%$ of the time above the rated capacity. This time decreased to $2.81 \%$ if charging was performed using $1.92 \mathrm{~kW}$ chargers.

A review of research regarding the combination of photovoltaic power generation and EV charging on city-scale was performed by Shepero, et al. [5]. Among other things, the authors found a lack of studies focusing on the combined variability in EV charging and PV modelling. Mureddu, et al. [11] investigated the energy balance between RES production and EV charging in the island of Sardinia in Italy. The results indicated that on an aggregated level, the RES can supply all EVs' charging load. However, shortages were observed in the large cities. Moreover, the temporal aspects of both loads were not studied. $\mathrm{Wu}$, et al. [12] developed a statistical method to account for the PV and EV variability in power flow analysis. The authors compared their method to the Monte Carlo power flow simulation on a 4.6 MVA grid in China with 3000 EVs and 1.5 MW PV capacity. In [13] the authors explored the impacts of $1700 \mathrm{EVs}$ and 3.5 MWp PV to the IEEE 33-node test feeder. The mean of the EV charging starting time was estimated to be between 00:00 and 01:30 and the standard deviation was 4.1-6.2 hours. The results showed that the dispersion of EVs improved the mean of the voltage, however, the variance was higher compared with the concentration of charging EVs in the grid. As it was expected, the uncertainty of the voltage values were higher when new uncertain loads, such as EV load or energy yield from PV panels, were introduced. The authors noted that the uncertainty impacts of the PV on the bus voltages were higher than that of the EVs.

Ko, et al. [14] investigated the trade-offs between vehicle energy consumption and on-site PV potential in the city of San Francisco, California. LiDAR and building footprint data were used to estimate the solar potential. The results showed that with the most efficient EVs $(0.19 \mathrm{kWh} / \mathrm{km})$ and PV panels (40.7\%, achieved by multi-junction concentrators) positive net energy balance can take place in most of the studied zones in the city. In [15], a similar study was made on the city of Auckland, New Zealand. The authors showed that regardless of the population density, there will be net energy balance will be positive. O'Brien, et al. [16] analysed the household energy balancing including public transportation in the city of Toronto, Canada. The net energy balance was negative in all the cases and all the population densities except for the low-density houses when highly efficient PV panels (20\%) and efficiency measures (30\% reduction in energy use) were adopted in houses. Denholm and Margolis [17] studied scenarios of up to 50\% PV integration in California, and found 
This is a postprint version of the final paper, which is accepted for publication in Energy:

https://doi.org/10.1016/j.energy.2018.11.050

that highly flexible energy systems, including EVs and optimised charging, could significantly reduce the need for energy storage.

\subsection{Contribution}

Several previous works studied the impacts of both EVs and PVs on the energy consumption on city scale. However, there are still some research gaps that need to be addressed, and the study presented here addresses the following of these:

- In [14-16], deterministic models for city scale EV and PV modelling were used. Stochastic modelling is used in this paper.

- None of the previous papers studied the self-consumption of the solar energy and the dependency on the season, which is done in this paper.

- The solar potential analysis presented here also included building façades, and not only rooftops.

- The EV and PV models are evaluated in two case studies for cities at high latitudes

\subsection{Electric vehicles in Sweden and Norway}

In 2017, battery electric vehicles (BEV) accounted for around 20\% of the new car sales, and plug-in hybrid electric vehicles (PHEV) for around 18\% in Norway. The current share of EVs in the personal vehicle fleet is around 5\%, or 10\% if PHEVs are also included [18] .

Due to focused policies and economic incentives, Norway has a high share of EVs compared to most countries. In the National Transportation Plan for 2018-2029 [19], the Norwegian government states that all new personal vehicles sold should be "zero emission vehicles" by 2025 . This is estimated to result in an BEV penetration level of up to $36 \%$ by 2025 and $60 \%$ by 2030 , or $40 \%$ and $63 \%$ if PHEVs are included [20].

Sweden has a goal of achieving a zero emission vehicle fleet by 2030 [21]. Some measures have been proposed to reach this goal such as 1) providing conditions required for renewable energy sources and electricity 2) encourage shift towards EVs and environmentally friendly vehicles 3 ) increase the carbon tax on cars.

\section{Method}

\subsection{Overview}

The analysis in this paper combines estimations on PV energy yield from available roof and façade areas with simulations of EV charging energy load. The analysis was performed to a number of scenarios regarding the level of PV integration on buildings and the level of EV penetration in the personal vehicle fleet. A flowchart describing the methodology is shown in Figure 1. 
This is a postprint version of the final paper, which is accepted for publication in Energy: https://doi.org/10.1016/j.energy.2018.11.050

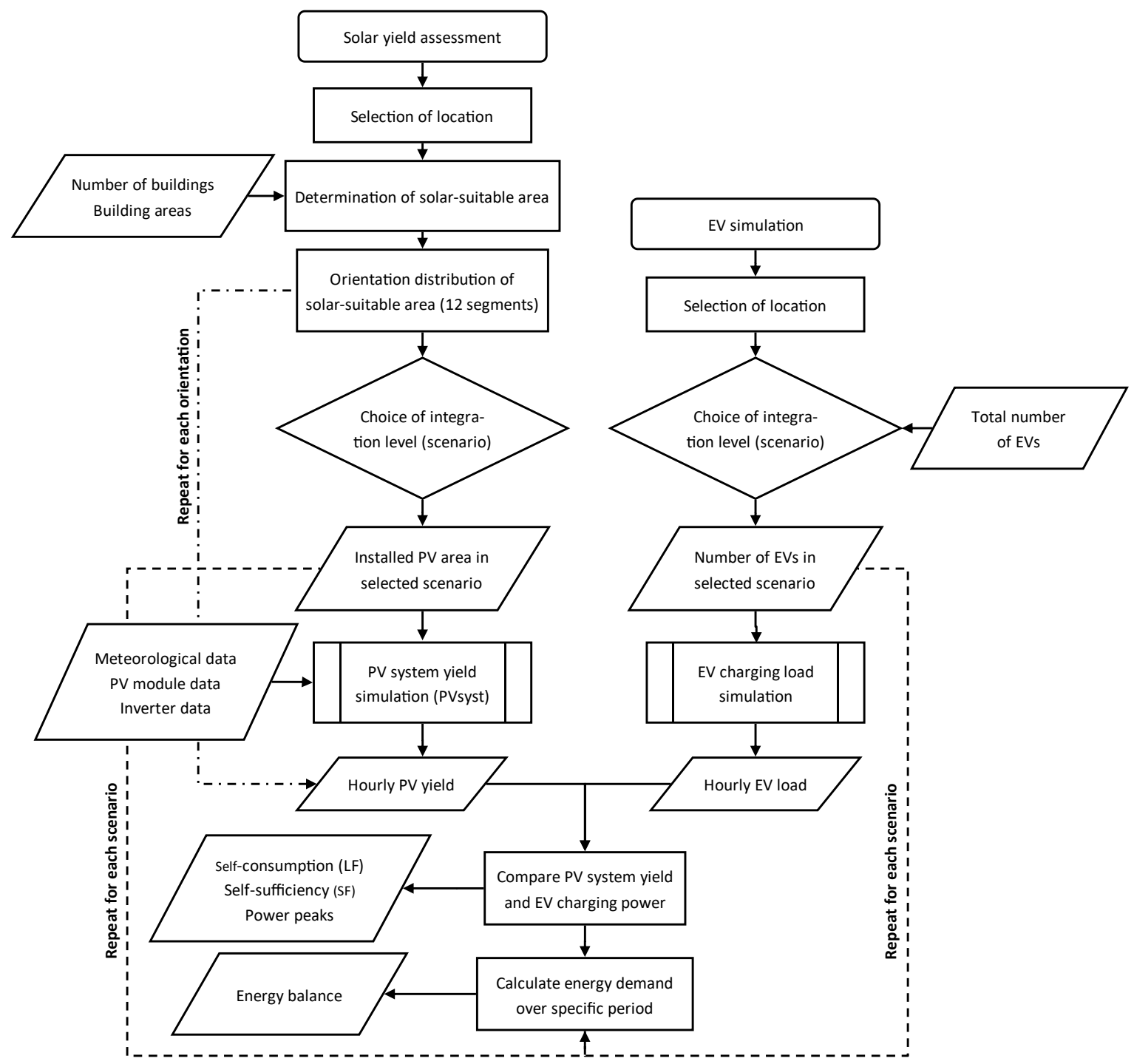

Figure 1. Flowchart giving an overview of the methodology used in the study.

The methodology for determining the solar-architecturally suitable area on roofs and facades is described in Section 2.2. The simulation of PV energy yield from the suitable areas is described in Section 2.3. The simulations of EV charging load are described in Section 2.5. Finally, Section 2.6 outlines how the simulated data were combined to evaluate the self-sufficiency and self-consumption of solar power for EV charging.

The methodology was applied to two case cities in Scandinavia: Troms $\emptyset$ in Northern Norway and Uppsala in Central Sweden. Building and EV statistics for the municipal area used in both cases. Troms $\varnothing\left(\mathrm{N} 70^{\circ}\right)$ is the largest city in Northern Norway, located $370 \mathrm{~km}$ north of the Arctic Circle. The 76000 inhabitants are distributed over two islands (Tromsøya and Kvaløya) and the main land. Uppsala $\left(59^{\circ} \mathrm{N}\right)$ is Sweden's fourth largest municipality in terms of population, with around 220000 inhabitants. The city is located just $70 \mathrm{~km}$ north of the capital Stockholm. 
This is a postprint version of the final paper, which is accepted for publication in Energy: https://doi.org/10.1016/j.energy.2018.11.050

\subsection{Determination of solar-architecturally suitable area}

\subsubsection{Calculation of roof and façade areas}

The available areas for PV installations were determined using the method proposed by IEA PVPS Task 7 [22]. Since detailed information about roof and façade areas is rarely available, this method is based on the ground floor area, $A_{g}$, of the buildings (the gross floor area) [22]. The suitable area for solar installations, $A_{\text {sol }}$, is calculated as

$$
A_{\text {sol }}=A_{g} \times u_{r}+A_{g} \times u_{f}
$$

where $u_{r}$ and $u_{f}$ are solar-architectural utilization factors for roof and façade areas, respectively.

In the IEA PVPS Task 7 method [22], the architectural suitability takes into account limitations due to e.g. construction, historical considerations, and shading. The solar suitability takes into account the relative solar irradiation on surfaces based on e.g. orientation, tilt angle and location. Based on a number of case studies performed in the IEA member countries [22], rule-of-thumb values for the solar-architectural utilization factors were determined to $u_{r}=0.4$ and $u_{f}=0.15$.

In the present study, the gross building area in Troms $\emptyset$ municipality was calculated using statistical data on the number of buildings by type from Statistics Norway (SSB) ${ }^{2}$ [23] . This data were combined with the information on the average area of each building type, which is available in [24]. The calculated gross building area of residential and non-residential buildings in the municipality is shown in Table 1, where the buildings are grouped according to the categories used in the Norwegian Ground Property, Address and Building Register (GAB). A more detailed description of the calculations for Troms $\varnothing$ is available in [25].

The number of buildings and the gross building area in Uppsala, shown in Table 2, was extracted directly from the database of statistics from Statistics Sweden (SCB), which keeps data on the number of buildings and total gross area of buildings by type [26]. In the analysis presented in this paper, the buildings in both locations have been re-grouped into only two categories: residential and nonresidential buildings.

\subsubsection{Building orientation and roof tilt}

Since the estimation was based on statistical data and not on maps, it was necessary to make some assumptions regarding building orientation and roof tilt.

All residential buildings were assumed to have sloped roofs with $30^{\circ}$ roof tilt angle. All nonresidential buildings, i.e. all other buildings than residential buildings, were assumed to have flat roofs. The same utilization factor $\left(u_{r}=0.4\right)$ was used for sloped as well as flat roofs [22].

Based on the work by Kjellsson [16], the orientations buildings were assumed to be equally distributed in all orientations (north, south, east and west). For sloped roofs, only buildings with roof orientations between east and west were considered to be suitable for solar energy utilization. To account for the orientation distribution, the suitable roof area was therefore divided into 12 evenly

\footnotetext{
${ }^{2}$ Data for Troms $\varnothing$ municipality were received upon request for SSB, since the data in the online
} database were only available at county level. 
spaced intervals between east $\left(-90^{\circ}\right)$ to west $\left(90^{\circ}\right)$. For flat roofs it was assumed that a PV system could be placed more or less freely on the roof, and all suitable roof area was included in the solar potential analysis.

The solar-suitable façade areas were calculated using the same utilization factor $\left(u_{f}=0.15\right)$ for residential and non-residential buildings. Only façade areas with and orientation between east and west were included (i.e. half of the available area).

The estimated solar-architecturally suitable roof and façade areas of buildings are shown along with the gross building areas in Table 1 and Table 2 for Troms $\varnothing$ and Uppsala, respectively.

Table 1. The estimated solar-architecturally suitable areas for PV installations in Tromsø.

\begin{tabular}{|c|c|c|c|c|c|}
\hline \multirow[t]{2}{*}{ Code } & \multirow[t]{2}{*}{ Building type } & \multirow[t]{2}{*}{$\begin{array}{l}\text { No. of } \\
\text { buildings }\end{array}$} & \multirow{2}{*}{$\begin{array}{l}\text { Gross } \\
\text { building } \\
\text { area }\end{array}$} & $\begin{array}{l}\text { Area, } \\
\text { roofs }\end{array}$ & \multirow{2}{*}{$\begin{array}{l}\begin{array}{l}\text { Area, } \\
\text { façades }\end{array} \\
m^{2}\end{array}$} \\
\hline & & & & $m^{2}$ & \\
\hline 1 & Dwelling & 31544 & 1293000 & 485000 & 3234000 \\
\hline 2 & Industrial building and warehouse & 4085 & 336000 & 126000 & 840000 \\
\hline 3 & Office and business building & 447 & 81000 & 30000 & 201000 \\
\hline 4 & Transport and communication building & 165 & 16000 & 6000 & 39000 \\
\hline 5 & Hotel and restaurant building & 265 & 21000 & 8000 & 52000 \\
\hline 6 & $\begin{array}{l}\text { Building used for education, public } \\
\text { entertainment and religious activities }\end{array}$ & 545 & 111000 & 42000 & 278000 \\
\hline 7 & Hospital and institutional care building & 59 & 14000 & 5000 & 36000 \\
\hline \multirow[t]{2}{*}{8} & $\begin{array}{l}\text { Prison, building for emergency } \\
\text { preparedness etc. }\end{array}$ & 34 & 3000 & 1000 & 7000 \\
\hline & Total & 37160 & $\begin{array}{r}4687000 \\
\left(4.7 \mathrm{~km}^{2}\right)\end{array}$ & $\begin{array}{r}1875000 \\
\left(1.9 \mathrm{~km}^{2}\right)\end{array}$ & $\begin{array}{r}703000 \\
\left(0.7 \mathrm{~km}^{2}\right)\end{array}$ \\
\hline
\end{tabular}

Table 2. The estimated solar-architecturally suitable areas for PV installations in Uppsala

\begin{tabular}{|c|c|c|c|c|c|}
\hline \multirow[t]{2}{*}{ Code } & \multirow[t]{2}{*}{ Building type } & \multirow[t]{2}{*}{$\begin{array}{l}\text { No. of } \\
\text { buildings }\end{array}$} & \multirow{2}{*}{$\begin{array}{l}\text { Gross } \\
\text { building } \\
\text { area } \\
\mathrm{m}^{2}\end{array}$} & \multirow{2}{*}{$\begin{array}{l}\text { Area, roofs } \\
m^{2}\end{array}$} & \multirow{2}{*}{$\begin{array}{l}\text { Area, façades } \\
m^{2}\end{array}$} \\
\hline & & & & & \\
\hline 1 & Residential building & 38274 & 6098000 & 2439000 & 915000 \\
\hline 2 & Industrial building & 828 & 886000 & 354000 & 133000 \\
\hline 3 & Building for public service purpose & 2025 & 1273000 & 509000 & 191000 \\
\hline 4 & Building for business purpose & 732 & 843000 & 337000 & 126000 \\
\hline 5 & Agricultural building & 51 & 26000 & 10000 & 4000 \\
\hline 6 & Supplementary building & 48925 & 4432000 & 1773000 & 665000 \\
\hline \multirow[t]{2}{*}{7} & Other building & 1002 & 129000 & 52000 & 19000 \\
\hline & Total & 91837 & $\begin{array}{r}13687000 \\
\left(13.7 \mathrm{~km}^{2}\right)\end{array}$ & $\begin{array}{r}5474000 \\
\left(5.5 \mathrm{~km}^{2}\right)\end{array}$ & $\begin{array}{r}2053000 \\
\left(2.0 \mathrm{~km}^{2}\right)\end{array}$ \\
\hline
\end{tabular}

\subsection{Assessment of $P V$ yield}

\subsubsection{Solar irradiation in Troms $\varnothing$ and Uppsala}

The annual relative solar irradiation, $I_{r}$, on surfaces with different orientations is shown in Figure 2 for Tromsø (top) and Uppsala (bottom), where 
This is a postprint version of the final paper, which is accepted for publication in Energy:

https://doi.org/10.1016/j.energy.2018.11.050

$$
I_{r}=I_{s} / I_{\max }
$$

$I_{s}\left(\mathrm{kWh} / \mathrm{m}^{2}\right)$ is the annual irradiation in surface $s$, and $I_{\max }\left(\mathrm{kWh} / \mathrm{m}^{2}\right)$ is the highest annual irradiation on a surface at the specific location.
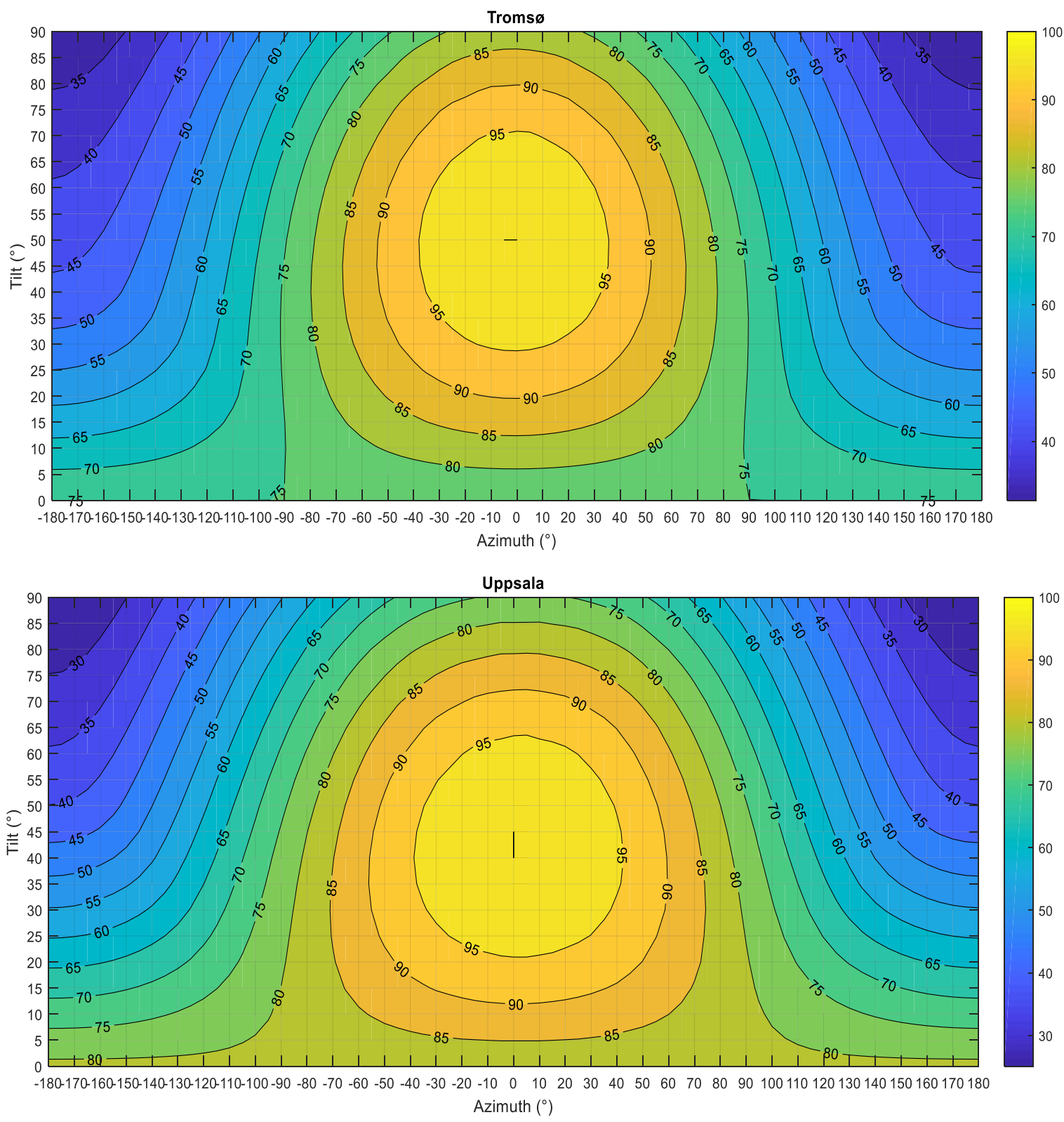

Figure 2. The relative irradiation $I_{r}$ on surfaces with different orientation (tilt and azimuth angles) in Tromsø (top) and Uppsala (bottom), given in percentage of the maximum possible irradiation.

For Troms $\varnothing$, surfaces with azimuth angles between approximately $-80^{\circ}$ (east) and $+80^{\circ}$ (west) and tilt angles of $5-90^{\circ}$ receive at least $80 \%$ of the maximum possible irradiation, which is defined as "good areas" in the IEA PVPS Task 7 method [22]. This range of orientations also includes south-facing façades. The optimal orientation in Troms $\emptyset$ is $5^{\circ}$ west with $60^{\circ}$ tilt angle, which receives around $980 \mathrm{kWh} / \mathrm{m}^{2}$ per year. Troms $\varnothing$, in contrast to Uppsala, is located in a mountainous region, and reason for the optimal orientation not being completely south in Troms $\varnothing$ is shading from peaks in the south. 
This is a postprint version of the final paper, which is accepted for publication in Energy:

https://doi.org/10.1016/j.energy.2018.11.050

For Uppsala, the range of orientations defined as good areas are azimuth angles between $-90^{\circ}$ (east) and $90^{\circ}$ (west) for tilt angles between $15^{\circ}$ and $85^{\circ}$. For lower tilt angles, the range of azimuth orientations is even wider, and the "good" range of orientations also includes horizontal surfaces. The optimal orientation in Uppsala is south-facing with $40^{\circ}$ tilt angle, which receives around $1200 \mathrm{kWh} / \mathrm{m}^{2}$ per year.

\subsection{PV yield simulation}

The potential yield of PV systems installed on the solar-suitable area was simulated using the software PVsyst [28] using meteorological data from Meteonorm v 7 [29] and horizon line from PVGIS 5 [30]. The solar energy yield was simulated for a $5.4 \mathrm{~kW}_{\mathrm{p}}$ PV system with monocrystalline silicon modules (see Table 3), and then normalized to energy output per $\mathrm{m}^{2}$ roof or façade area. The module efficiency was set to around $18 \%$, which is slightly higher than the average $17 \%$ for commercial modules today [31], in order to match a near future scenario.

Table 3. Details of the simulated 5.4 kWp PV system, including 18 modules and one inverter.

\begin{tabular}{ll}
\hline Module & \\
Type & Jinkosolar, JKM300M-60 \\
Power & $300 \mathrm{~kW}_{\mathrm{p}}$ \\
Efficiency & $18.42 \%$ \\
Module area & $1.637 \mathrm{~m}^{2}$ \\
Number of modules & 18 \\
Inverter & \\
Type & $\mathrm{AEG}, \mathrm{AS}-\mathrm{IR} 01-4600$ \\
Inverter power & $4.6 \mathrm{~kW}$ AC \\
European efficiency & $96.8 \%$ \\
Power ratio (PV array/inverter) & 1.17 \\
\hline
\end{tabular}

For residential building roofs, the PV system was simulated with a tilt angle of $30^{\circ}$, i.e. mounted flat on the roof, and individually for each the 12 orientation intervals described in Section 2.2.2.

A different design approach was necessary for flat, non-residential roofs. There are basically two design strategies for PV systems on flat roofs: higher tilt angles and high energy output per module, or lower tilt angles but a higher number of modules on the same available area. High tilt angles require larger spacing between PV rows to avoid self-shading, e.g. around $2.7 \mathrm{~m}$ for PV modules with $30^{\circ}$ tilt in Troms $\varnothing^{3}$. With lower tilt angles it is possible to fit a higher number of modules on the same area. The influence of PV system orientation on flat roofs on the energy output is discussed in more detail in for example [33] and [34].

In practice, many large-scale PV systems use dual PV rows with low (10-20 $)$ tilt angles, facing east and west (Figure 3) to fit as many modules as possible on a given area. Using dual rows, it is possible to mount the opposite facing module within this distance without causing additional shading, thereby increasing the space efficiency. Another potential benefit of dual rows is a more even energy yield

${ }^{3}$ Estimated using sun height of $15^{\circ}$ as the limitation (around mid-February in Tromsø) for $1 \mathrm{~m} \times 1.6 \mathrm{~m}$ modules with landscape orientation, using the calculation method described in [32]. 
over the course of the day compared to south facing rows, due to higher energy yield in the morning and afternoon. It should, however, be noted that this type of system is more exposed to snow cover than a system with higher tilt angle, where the snow can more easily slide off the modules.

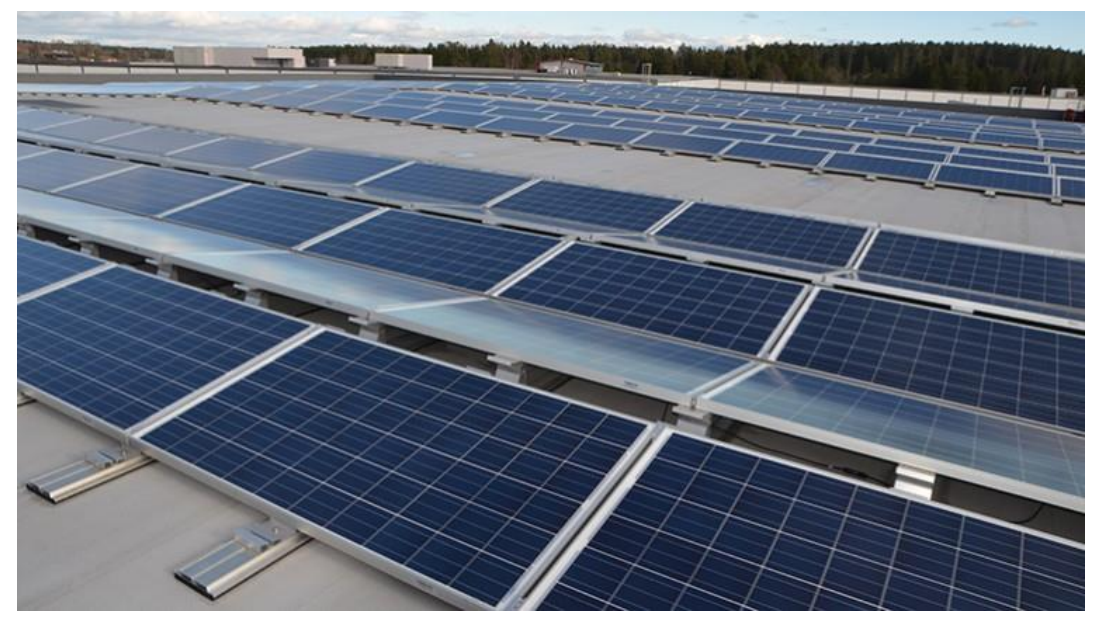

Figure 3. East-west facing rows of PV modules with low tilt angle on one of Norway's largest PV systems at ASKO Øst in Vestby. Photo: Jan Erik Røine/Norsk VVS (used with permission).

With reference to the discussion above, PV installations on non-residential (flat) roofs were assumed to be installed with east/west facing rows at $15^{\circ}$ tilt. As described in Section 2.2.2, building orientation was not considered for flat roofs.

In the case of the façade areas, PV systems were assumed to be mounted flat on the facades, i.e. with $90^{\circ}$ tilt angle. Similarly to the residential roof systems, the façade mounted PV systems were simulated individually for each of the 12 orientations intervals described in Section 2.2.2.

For all three area categories (residential roofs, non-residential roofs, and facades), the annual energy output was normalized per installed PV area $\left(\mathrm{kWh} / \mathrm{m}^{2}\right)$ and multiplied with the total solararchitecturally suitable area in each category to estimate the total solar energy potential.

The normalized energy yield per installed power $\left(\mathrm{kW}_{\mathrm{p}}\right)$ and installed PV area $\left(\mathrm{m}^{2}\right)$ roofs and façades for each of the orientations are shown in Table 4. In this case of flat roofs, the energy output is normalized by the projected system area on the flat roof, which also includes $0.6 \mathrm{~m}^{2}$ spacing between each PV module row. The energy output normalized by active PV area is $117 \mathrm{kWh} / \mathrm{m}^{2}$ and $170 \mathrm{kWh} / \mathrm{m}^{2}$ for Troms $\emptyset$ and Uppsala, respectively. 
This is a postprint version of the final paper, which is accepted for publication in Energy: https://doi.org/10.1016/j.energy.2018.11.050

Table 4. The normalized energy yield $\left(\mathrm{kWh} / \mathrm{kW}_{\mathrm{p}}\right)$ for a PV system in Tromsø and Uppsala for the 12 orientations between east and west. The values were simulated in PVsyst and normalized by the installed area.

\begin{tabular}{|c|c|c|c|c|c|c|}
\hline \multirow[t]{3}{*}{$\begin{array}{l}\text { Roof/façade } \\
\text { orientation }\end{array}$} & \multicolumn{2}{|c|}{$\begin{array}{l}\text { Energy yield, sloped roofs } \\
\left.\text { (30 } 0^{\circ} \text { tilt }\right)\end{array}$} & \multicolumn{2}{|c|}{$\begin{array}{l}\text { Energy yield, flat roofs }\left(15^{\circ}\right. \\
\text { tilt, dual orientation) }\end{array}$} & \multicolumn{2}{|c|}{ Energy yield, façades } \\
\hline & Tromsø & Uppsala & Tromsø & Uppsala & Tromsø & Uppsala \\
\hline & $k W h / k W_{p}$ year & $k W h / k W_{p}$ year & $k W h / k W_{p}$ year & $k W h / k W_{p}$ year & $k W h / k W_{p}$ year & $k W h / k W_{p}$ year \\
\hline$-90^{\circ}$ to $-75^{\circ}$ & 637 & 882 & \multirow{12}{*}{$\begin{array}{l}\text { (same for all } \\
\text { orientations) }\end{array}$} & \multirow{12}{*}{$\begin{array}{l}\text { (same for all } \\
\text { orientations) }\end{array}$} & 472 & 638 \\
\hline$-75^{\circ}$ to $-60^{\circ}$ & 675 & 938 & & & 517 & 706 \\
\hline$-60^{\circ}$ to $-45^{\circ}$ & 712 & 987 & & & 557 & 758 \\
\hline$-45^{\circ}$ to $-30^{\circ}$ & 745 & 1026 & & & 601 & 802 \\
\hline$-30^{\circ}$ to $-15^{\circ}$ & 767 & 1050 & & & 635 & 826 \\
\hline$-15^{\circ}$ to $0^{\circ}$ & 783 & 1065 & & & 664 & 837 \\
\hline $0^{\circ}$ to $15^{\circ}$ & 788 & 1066 & & & 677 & 752 \\
\hline $15^{\circ}$ to $30^{\circ}$ & 782 & 1053 & & & 680 & 828 \\
\hline $30^{\circ}$ to $45^{\circ}$ & 767 & 1030 & & & 667 & 809 \\
\hline $45^{\circ}$ to $60^{\circ}$ & 739 & 991 & & & 635 & 766 \\
\hline $60^{\circ}$ to $75^{\circ}$ & 705 & 946 & & & 593 & 714 \\
\hline $75^{\circ}$ to $90^{\circ}$ & 657 & 885 & & & 511 & 616 \\
\hline \multicolumn{7}{|l|}{$\begin{array}{l}\text { Avg. all } \\
\text { orientations }\end{array}$} \\
\hline$\underset{\mathrm{kWh} / \mathrm{kW}_{\mathrm{p}}}{\mathrm{kW} / \mathrm{m}^{2}}$ & $\begin{array}{l}730 \\
124\end{array}$ & $\begin{array}{l}993 \\
168\end{array}$ & $\begin{array}{c}580 \\
98\end{array}$ & $\begin{array}{l}840 \\
142\end{array}$ & $\begin{array}{l}601 \\
102\end{array}$ & $\begin{array}{l}754 \\
128\end{array}$ \\
\hline
\end{tabular}

\subsubsection{PV simulation scenarios}

The energy yield from PV systems was estimated for five scenarios with increasing integration level, as shown in Table 5 .

Table 5. The assumptions in the simulated PV scenarios

\begin{tabular}{ll}
\hline Parameter & Simulated scenarios \\
\hline $\begin{array}{l}\text { Integration level (percentage of suitable } \\
\text { roof and façade areas) }\end{array}$ & $10 \%, 25 \%, 50 \%, 75 \%, 100 \%$ \\
\hline
\end{tabular}

Integration level of PV in the urban environment is here defined as the percentage of the suitable roof and façade area (Table 1 and Table 2) that is used for PV installations, No distinction was made between new and old buildings, nor based on orientation of the buildings. That is, $10 \%$ of the roofs includes $10 \%$ of all suitable roofs, not just those with optimal orientation.

\subsection{EV charging simulations}

In this Section, a summary of the EV model is provided in Section 2.5.1 followed by the assumed model parameters in the simulations in Section 2.5.2.

\subsubsection{EV charging model}

The spatio-temporal mobility of EVs was modeled using a Markov chain model.The model is presented in detail in [35], and a brief summary of this model is provided here.

Markov chains have been previously used to model the mobility of cars in cities [6, 8, 9]. A Markov chain is a memoryless stochastic process in which the probability of being in a specific state depends only on the previous state [36]. For example the stochastic process $\left\{X_{t}\right\}_{t=0}^{\infty}$ is a Markov process if 
This is a postprint version of the final paper, which is accepted for publication in Energy: https://doi.org/10.1016/j.energy.2018.11.050

$$
P\left(X_{t+1}=j \mid X_{t}=i, \ldots, X_{1}, X_{0}\right)=P\left(X_{t+1}=j \mid X_{t}=i\right)=p_{i j},
$$

where $i$ and $j$ are in the set of the states of the process $S$ and $p_{i j}$ is the probability of switching from state $i$ to state $j[36]$.

The proposed model assumed that EVs mobilize between parking locations in the city. The states of the model $S$ represented the parking profiles Home, Work and Other, i.e., $S=\{$ Home, Work, Other . These three parking profiles were previously identified in [37], [38] and were used in [8]. These parking profiles represented parking to visit residential, workplace, and other buildings, respectively. The switching probabilities between states can be arranged in the $3 \times 3$ matrix $M$.

$$
M=\left(\begin{array}{lll}
p_{11} & p_{12} & p_{13} \\
p_{21} & p_{22} & p_{23} \\
p_{31} & p_{32} & p_{33}
\end{array}\right)
$$

where the indices $\{1,2,3\}$ represent the states Home, Work, Other.

The mobility of cars in cities was shown to have a diurnal and weekday/weekend patterns [8] and [39]. The developed model accounts for these patterns by defining a non-homogeneous Markov chain such that the probability of switching between states $p_{i j}$ became dependent on the time-of-transition, i.e., $p_{i j}^{\tau}$. The variable $\tau$ represented the minute of transition during the day - thereby accounting for the diurnal patterns - and whether the transition occurs in a weekday or a weekend. In total, the value of $\tau$ was in the set $\{1, \ldots, 1440,1441, \ldots, 2880\}$, where the first 1440 values represented the minutes of a weekday and the second 1440 values represented the minutes of a weekend. The Swedish travel survey was used to estimate the probabilities of the Markov chain [40] consult [8] for a detailed description of this process.

The state of charge (SOC) $E_{t}(\mathrm{kWh})$ of an EV at time $t$ can be estimated from

$$
E_{t}= \begin{cases}E_{t}+C \times \Delta t, & \text { if charging } \\ E_{t}-d \times \eta, & \text { if driving } \\ E_{t}, & \text { else }\end{cases}
$$

where $C$ is the charging power $(\mathrm{kW}), d$ is the driving distance $(\mathrm{km})$ travelled in every time-step, and $\eta$ is the AC electricity consumption rate $(\mathrm{kWh} / \mathrm{km})$ [8]. In this study, a maximum SOC for the EV batteries was not explicitly specified in the model, instead the decrease in the SOC was modelled. This is to say that the authors assumed that the battery capacities of the EVs are large enough to meet the drivers' needs, possibly in the near future. The EVs in the study were assumed to charge opportunistically in all the parking locations. The charging load of EVs in the city $P_{E V}(\mathrm{~kW})$ can be estimated as

$$
P_{E V}=C \times n_{t},
$$

where $n_{t}$ is the number of charging EVs in the city at time $t$. The authors simulated two summer and two winter weeks. The differences between summer and winter is attributed to the seasonal differences in the AC electricity consumption $\eta$. The authors assumed $\eta$ to be $0.25 \mathrm{kWh} / \mathrm{km}$ and $0.15 \mathrm{kWh} / \mathrm{km}$ for winter and summer, respectively [41]. EVs consume more energy during cold weathers due to heating, see $[42,43]$ for a detailed estimate of the impacts of the ambient temperature on $\eta$. 
The large number of simulated EVs reduces the randomness in the daily charging load. In other words, the randomness in the individual mobility patterns is less conspicuous when a large number of EVs is simulated, see the results in [10] and [44]. Consequently, the charging load of the simulated winter and summer weeks was assumed to be representative of the winter and summer seasons.

\subsubsection{EV simulation scenarios}

Several combinations of penetration levels and charging powers were simulated in this study. Each simulation presents a possible future scenario. A summary of the assumed parameters in the simulated scenarios is provided in Table 6.

Table 6. The assumptions of the EV model parameters in the simulated scenarios.

\begin{tabular}{ll}
\hline Parameter & Simulated scenarios \\
\hline Penetration level & $10 \%, 25 \%, 50 \%, 75 \%, 100 \%$ \\
Charging power C & $3.7 \mathrm{~kW}, 6.9 \mathrm{~kW}, 22 \mathrm{~kW}$ \\
\hline
\end{tabular}

The current (May 2018) number of EVs in Troms $\varnothing$ is 1390 (784 BEV and 606 PHEV) [45] and 714 in Uppsala (217 BEV and 497 PHEV) [46]. The current situation was not simulated as a scenario, due to the relatively small number of EVs. The total number of personal vehicles is 33072 and 83147 in Troms $\varnothing$ and Uppsala, respectively. The current penetration level of EVs in both cities is $4.2 \%$ and $0.9 \%$, respectively. The authors chose to simulate various higher penetration levels, as shown in Table 6 , to represent different future cases.

As regards the charging power $C$, the authors simulated three possible scenarios: $3.7 \mathrm{~kW}, 6.9 \mathrm{~kW}$, and $22 \mathrm{~kW}$. The $3.7 \mathrm{~kW}$ charging power represents the $16 \mathrm{~A}$ single-phase charging. The 6.9 A represents the $10 \mathrm{~A}$ three-phase charging. A semi-fast charging was simulated using a $22 \mathrm{~kW}$ charger, which represent $32 \mathrm{~A}$ three-phase charging. The $3.7 \mathrm{~kW}$ and $22 \mathrm{~kW}$ chargers are used by $79 \%$ of the chargers in Uppsala [47], while the $6.9 \mathrm{~kW}$ was simulated following [7]. A study from 2016 revealed that $80 \%$ of Norwegian EV charging is done with 16A fuses, but that power levels between $2 \mathrm{~kW}$ and $22 \mathrm{~kW}$ are used in home charging [48]. The study also predicted that higher power levels will become more common in the coming years, as the battery capacity of EVs increase.

Fast charging, with charging power levels of $50-150 \mathrm{~kW}$, or even higher, was not simulated here, as this type of charging is so far not common in urban locations. Future development of fast charging is studied in e.g. [49].

\subsection{Solar fraction and load fraction}

The self-consumption of solar power in buildings with and without EVs have been extensively studied, for example by [50]. Luthander, et al. [51] presented a review of the numerous metrics that are used to describe self-consumption and self-sufficiency.

The solar power self-sufficiency, commonly referred to as the solar fraction $(S F)$, describes how much of the load that can be covered by solar power. Using the terminology from [50] and [51], the solar fraction can be described by

$$
S F=\frac{\int_{t=t_{1}}^{t_{2}} M(t) d t}{\int_{t=t_{1}}^{t_{2}} L(t) d t}
$$


where $M(t)$ is the instantaneously overlapping part of the PV generation profile, $P(t)$, and the load profile, $L(t)$, defined by

$$
M(t)=\min \{L(t), P(t)\} .
$$

Correspondingly, the self-consumption of solar energy, here described by the load fraction $(L F)$, is the fraction of the available solar power that is directly used by the load. $L F$ is defined as $[50,51]$

$$
L F=\frac{\int_{t=t_{1}}^{t_{2}} M(t) d t}{\int_{t=t_{1}}^{t_{2}} P(t) d t} .
$$

Both $S F$ and $L F$ are in the range [0,1], where $S F=1$ means that the full energy demand is covered by solar energy, and $L F=1$ means that all solar energy is self-consumed to cover the load. The values of $S F$ and $L F$ depend, among other factors, on the integration period, which is typically one year, and the time resolution of the data. For yearly comparisons, the solar fraction can be calculated using monthly or even total yearly data. For a net zero energy building, the solar fraction equals the load fraction if calculated over a whole year [50]. This time resolution does not, however, capture the fluctuations in power which are important to minimise the strain on the electricity grid [52].

In the study presented here, $S F$ and $L F$ were calculated for two weeks in winter (March) and two weeks in summer (July), using hourly time resolution. These two periods are assumed to cover the two "worst case" periods of the year, i.e. the highest EV load (winter) and the highest PV power output (summer). Troms $\varnothing$ has around two months without sun during the polar night between 27 November and 15 January. This period is not considered in this study, since the focus is on the load match between PV and EV, and how to improve it.

In addition, the instantaneous solar fraction, $S F(t)$, and load fraction, $L F(t)$, were used in the analysis. They are here defined according to

and

$$
S F(\mathrm{t})=\frac{M(t)}{L(t)}
$$

$$
L F(\mathrm{t})=\frac{M(t)}{P(t)}
$$

Both the solar fraction and the load fraction describe the overlapping parts of the power and load profiles. The non-overlapping parts, i.e. the power that is exported and imported from the grid, are described by grid-integration factors [51]. An overview of grid-integration factors, with a focus on zero energy buildings, is given by Sartori, et al. [52]. In the present study, the grid interaction was evaluated by evaluating the largest peaks in power exported to the grid (excess PV power) and power imported from the grid (unmet EV load).

\section{Results}

\subsection{PV power output}

The solar energy yield from $10 \%$ of the estimated suitable areas on roofs and façades in shown in Figure 4 for Troms $\varnothing$ and for Uppsala. Total annual yield from the different integration levels are given 
in Table 7. The hourly yield for one week in winter (March) and one week in summer (July) is shown for Troms $\varnothing$ and Uppsala in Figure 5 and Figure 6, respectively.

The total simulated energy output in Uppsala is around four times that in Tromsø, mainly due to the larger building footprint area (and thereby available area for solar installations). The building footprint area in Uppsala is 2.9 times larger than in Troms $\varnothing$, while the energy output is around 4 times larger. The energy output in the two cities normalized by the solar-suitable area on roofs and façades is $110 \mathrm{kWh} / \mathrm{m}^{2}$ per year for Troms $\emptyset$ compared to $153 \mathrm{kWh} / \mathrm{m}^{2}$ per year for Uppsala.
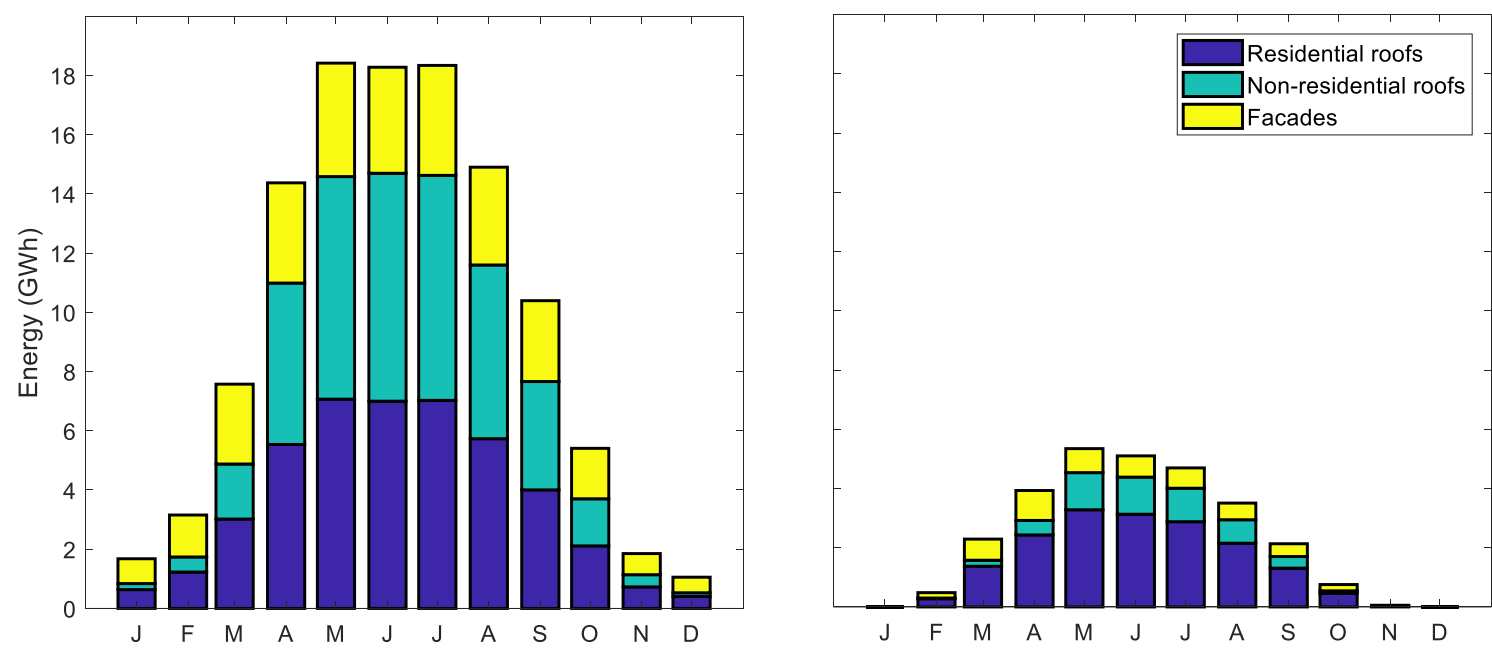

Figure 4. The monthly energy yield from $10 \%$ of suitable areas in Uppsala (left) and Tromsø (right).

As the graph for Tromsø in Figure 4 shows, there is no yield during November, December and January in Troms $\varnothing$ since the sun never rises above the horizon during this time (the polar night).

Table 7. The annual energy yield in GWh from PV installations on suitable areas in Uppsala and Tromsø.

\begin{tabular}{c|cccc|cccc}
\hline $\begin{array}{c}\text { PV int. } \\
\text { level }\end{array}$ & $\begin{array}{c}\text { Res. } \\
\text { roofs }\end{array}$ & $\begin{array}{c}\text { Non-res. } \\
\text { roofs }\end{array}$ & Façades & Total & $\begin{array}{c}\text { Tromsø } \\
\text { Res. } \\
\text { roofs }\end{array}$ & $\begin{array}{c}\text { Non-res. } \\
\text { roofs }\end{array}$ & Façades & Total \\
\hline & GWh & GWh & GWh & GWh & GWh & GWh & GWh & GWh \\
$10 \%$ & 44 & 42 & 28 & 115 & 17 & 6 & 5 & 28 \\
$25 \%$ & 111 & 106 & 71 & 289 & 43 & 14 & 13 & 71 \\
$50 \%$ & 222 & 212 & 142 & 577 & 87 & 28 & 27 & 142 \\
$75 \%$ & 334 & 319 & 213 & 866 & 130 & 42 & 40 & 212 \\
$100 \%$ & 445 & 425 & 284 & 1154 & 173 & 56 & 54 & 283 \\
\hline
\end{tabular}

The potential in Troms $\varnothing$ was found to be largest from roofs of residential buildings (i.e. sloped roofs), which accounted for around $60 \%$ of the total energy yield. The relative contribution from façades was larger during the winter weeks for both locations, due to the lower sun angles, while to relative contribution from non-residential (flat) roofs was larger during summer. In Uppsala, the contribution from residential and non-residential roofs were almost equal in summer, while the contribution from residential roofs and façades was almost equal during the winter weeks. 


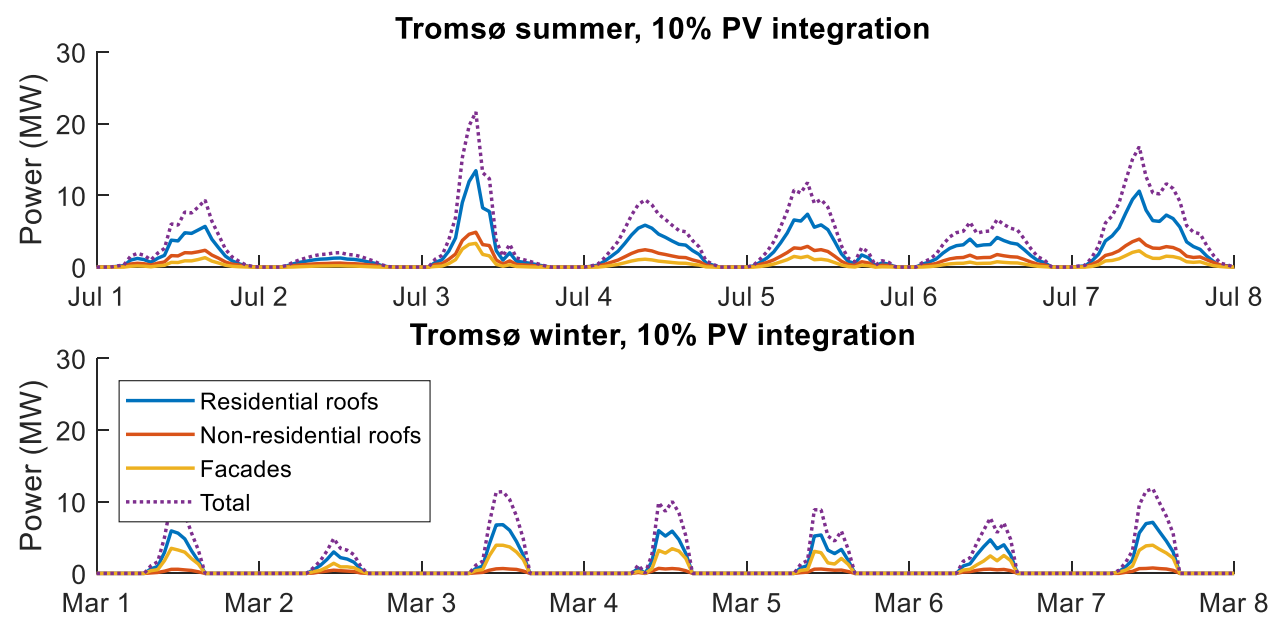

Figure 5. The hourly PV yield in Tromsø for the first week in March and July with $10 \%$ PV integration.
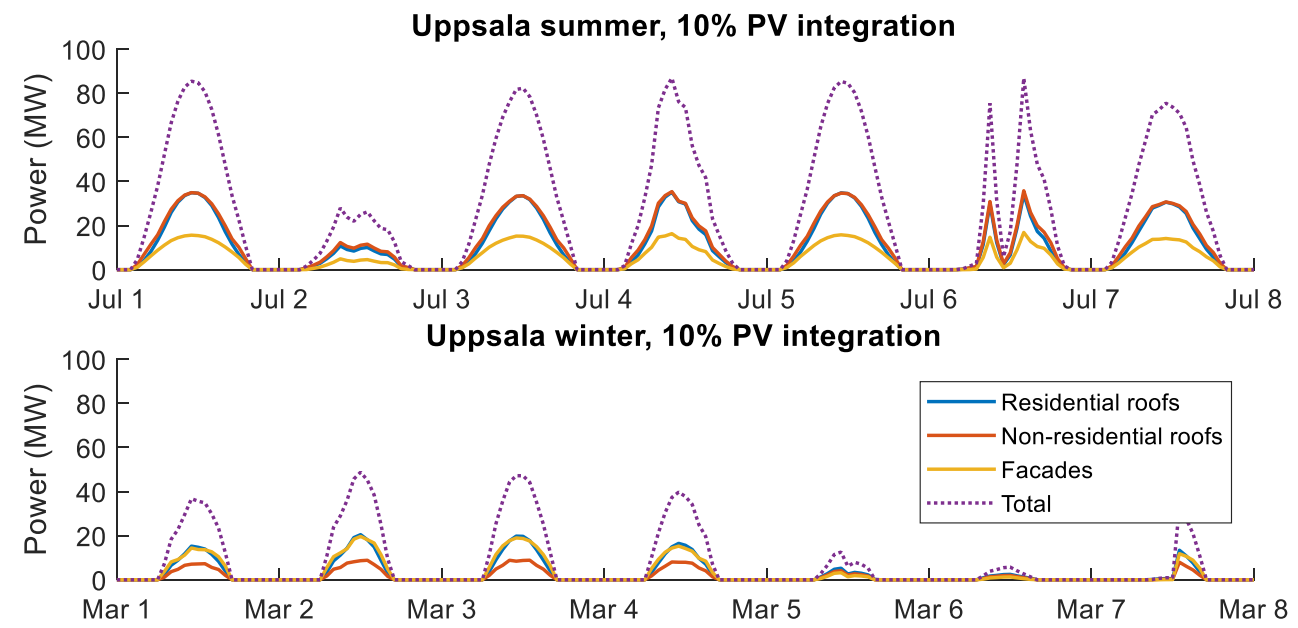

Figure 6. The hourly PV yield in Uppsala for the first week in March and July with $10 \%$ PV integration.

\subsection{EV charging load}

The charging load from different charging locations is shown for the first week in March for Uppsala (top) and Troms $\varnothing$ (bottom) in Figure 7. In both cases, the load is shown for $10 \%$ EV penetration and a charging power of $3.7 \mathrm{~kW}$. The total charging load is shown as a dotted line in the graphs. The difference between the summer and winter week is a generally higher charging level during winter due to higher energy consumption of EVs at lower temperatures.

There is a distinctive difference between workplace charging, with the highest peak during morning and midday, and residential charging, with the highest peak during the evening and night. The load profile of "Other" charging stations, for example at public parking places, is more evenly distributed during the day, although there is a small peak in the afternoon at the same time as for residential charging. This charging pattern is due to after-work activities such as shopping or visiting the gym. 


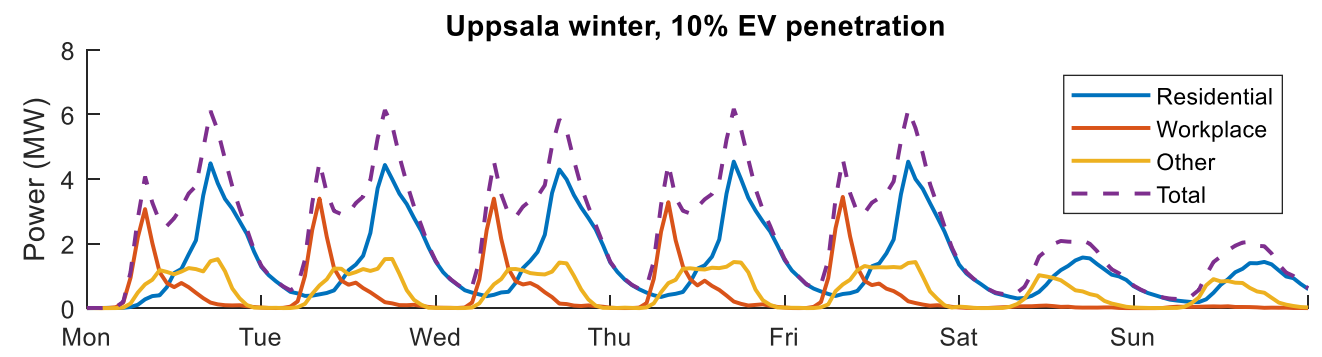

Tromsø winter, $10 \%$ EV penetration

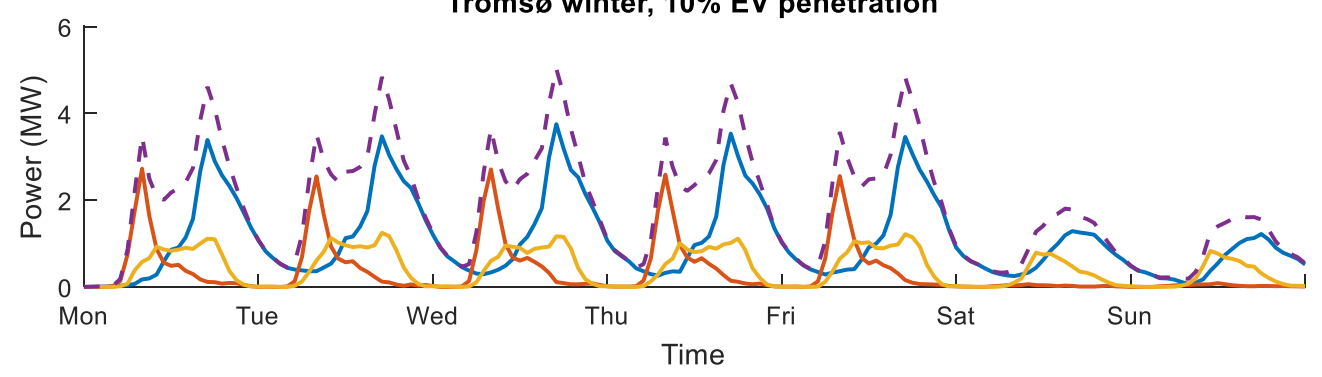

Figure 7. The simulated residential, workplace, other, and total charging load for one $10 \% \mathrm{EV}$ penetration in Uppsala (8315 EVs, top graph) Tromsø (3306 EVs, bottom graph). The load pattern is shown for one week in March with $3.7 \mathrm{~kW}$ charging power. Note that the scale on the $y$-axis is different for the two graphs.

The influence of charging power is shown in Figure 8, where the simulated residential, workplace, other, and total charging profiles are shown for the three charging power levels $3.7 \mathrm{~kW}, 6.9 \mathrm{~kW}$, and $22 \mathrm{~kW}$. The charging profiles are shown for two days in winter, i.e. the worst-case scenario in terms of EV charging load. The load profiles for Friday and Saturday to include one weekday and one day during the weekend. The scenario with $10 \% \mathrm{EV}$ penetration in Uppsala is shown as an example, but the shape of the profiles are similar for Uppsala. The higher charging power results in higher peaks in charging power, but also in longer times with low or no charging, and the $3.7 \mathrm{~kW}$ charging power accordingly results in a smoother charging profile. 

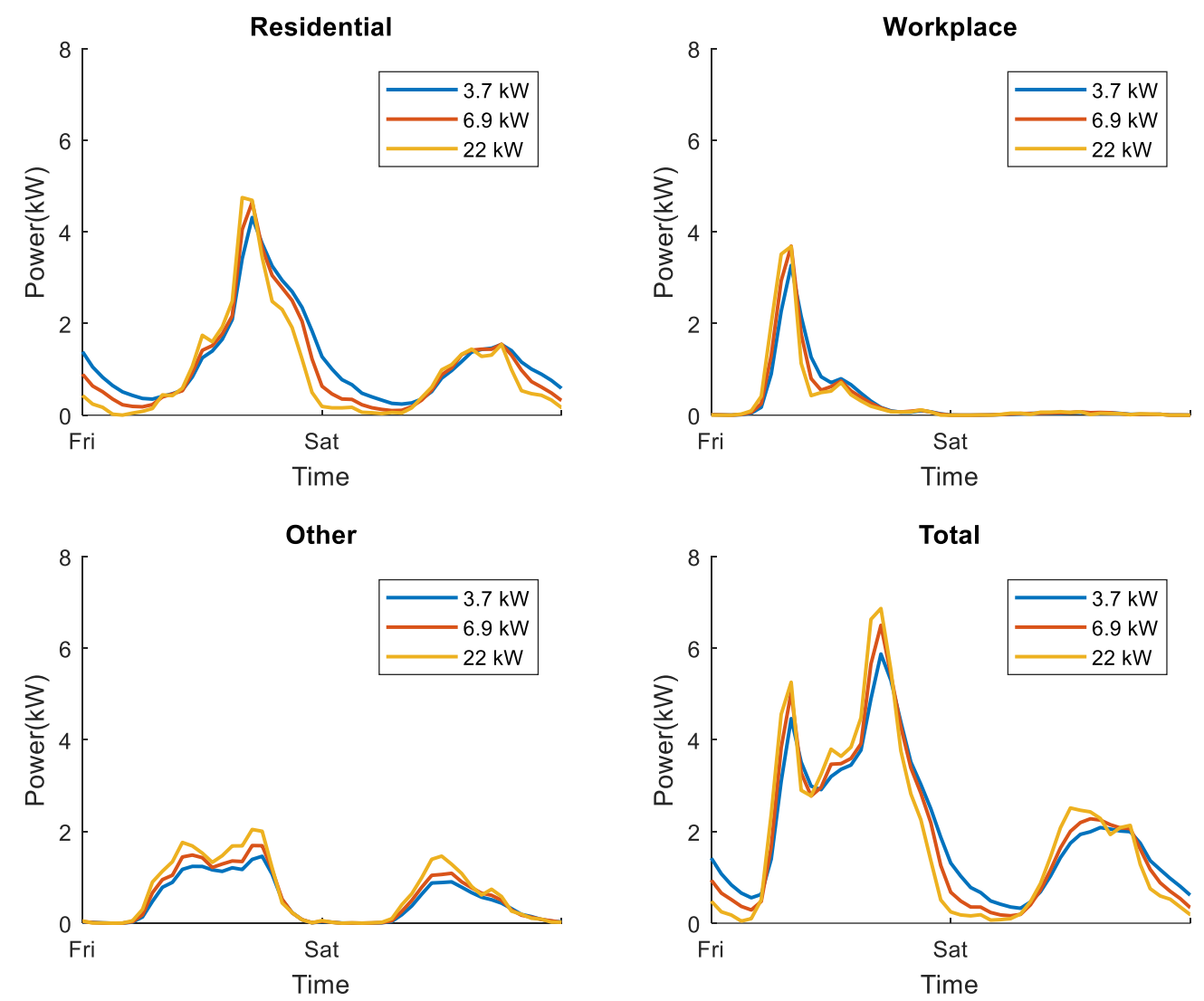

Figure 8. The influence of charging power on charging load profiles is shown for two randomly chosen days (Friday and Saturday) in winter with $10 \% \mathrm{EV}$ penetration in Uppsala.

\subsection{Solar fraction and load fraction}

Table 8 to Table 11 show $S F$ and $L F$ for each of the scenarios. As defined in Section 2.6, $S F$ describes to what extent the load is covered by solar energy over a defined time period, and $L F$ to what extent the generated solar power that is used by the load. The higher $S F$ is, the more of the EV charging is covered by solar power. The higher the $L F$ is, the more of PV power can be used directly for EV charging. The greyed out cells in each of the tables show the scenarios for which there is a negative energy balance, i.e. when the total EV load is higher than the total PV yield.

$S F$ and $L F$ for the two winter weeks (in March) in Table 8 for Troms $\varnothing$ and Table 10 for Uppsala, and for the two summer weeks (in July) in Table 9 (Tromsø) and Table 11 (Uppsala). The solar fraction and load fraction for the total aggregated charging load and $3.7 \mathrm{~kW}$ charging power is shown for the five EV integration levels and five PV integration levels. The PV integration level in the tables refers to the percentage of all solar-architecturally suitable areas on all types of buildings, i.e. roofs and façades on residential and non-residential buildings. 
This is a postprint version of the final paper, which is accepted for publication in Energy:

https://doi.org/10.1016/j.energy.2018.11.050

Table 8. The solar fraction $(S F)$ for the total aggregated load in Tromsø for two weeks in March. The PV integration levels refer to the percentage of suitable areas on roofs and façades for all types of buildings. The charging power was $3.7 \mathrm{~kW}$.

\begin{tabular}{|c|c|c|c|c|c|c|c|c|c|c|}
\hline \multirow{3}{*}{$\begin{array}{c}\text { EV } \\
\text { penetration } \\
\text { level }\end{array}$} & \multicolumn{10}{|c|}{ PV integration level } \\
\hline & \multicolumn{2}{|c|}{$10 \%$} & \multicolumn{2}{|c|}{$25 \%$} & \multicolumn{2}{|c|}{$50 \%$} & \multicolumn{2}{|c|}{$75 \%$} & \multicolumn{2}{|c|}{$100 \%$} \\
\hline & $S F$ & $L F$ & $S F$ & $L F$ & $S F$ & $L F$ & $S F$ & $L F$ & $S F$ & $L F$ \\
\hline $10 \%$ & 0.41 & 0.17 & 0.43 & 0.07 & 0.43 & 0.04 & 0.44 & 0.02 & 0.44 & 0.02 \\
\hline $25 \%$ & 0.35 & 0.36 & 0.41 & 0.17 & 0.43 & 0.09 & 0.43 & 0.06 & 0.43 & 0.05 \\
\hline $50 \%$ & 0.30 & 0.62 & 0.36 & 0.30 & 0.41 & 0.17 & 0.43 & 0.12 & 0.43 & 0.09 \\
\hline $75 \%$ & 0.26 & 0.81 & 0.34 & 0.43 & 0.38 & 0.24 & 0.41 & 0.17 & 0.42 & 0.13 \\
\hline $100 \%$ & 0.22 & 0.90 & 0.32 & 0.53 & 0.36 & 0.30 & 0.39 & 0.22 & 0.41 & 0.17 \\
\hline
\end{tabular}

Table 9. The solar fraction ( $S F$ ) for the total aggregated load in Tromsø for two weeks in July. The PV integration levels refer to the percentage of suitable areas on roofs and façades for all types of buildings. The charging power was $3.7 \mathrm{~kW}$.

\begin{tabular}{|c|c|c|c|c|c|c|c|c|c|c|}
\hline \multirow{3}{*}{$\begin{array}{c}\text { EV } \\
\text { penetration } \\
\text { level }\end{array}$} & \multicolumn{10}{|c|}{ PV integration level } \\
\hline & \multicolumn{2}{|c|}{$10 \%$} & \multicolumn{2}{|c|}{$25 \%$} & \multicolumn{2}{|c|}{$50 \%$} & \multicolumn{2}{|c|}{$75 \%$} & \multicolumn{2}{|c|}{$100 \%$} \\
\hline & $S F$ & $L F$ & $S F$ & $L F$ & $S F$ & $L F$ & $S F$ & $L F$ & $S F$ & $L F$ \\
\hline $10 \%$ & 0.82 & 0.08 & 0.87 & 0.03 & 0.89 & 0.02 & 0.89 & 0.01 & 0.90 & 0.01 \\
\hline $25 \%$ & 0.73 & 0.18 & 0.82 & 0.08 & 0.86 & 0.04 & 0.88 & 0.03 & 0.88 & 0.02 \\
\hline $50 \%$ & 0.63 & 0.31 & 0.76 & 0.15 & 0.82 & 0.08 & 0.84 & 0.05 & 0.86 & 0.04 \\
\hline $75 \%$ & 0.57 & 0.41 & 0.70 & 0.21 & 0.79 & 0.11 & 0.82 & 0.08 & 0.84 & 0.06 \\
\hline $100 \%$ & 0.52 & 0.50 & 0.66 & 0.26 & 0.76 & 0.15 & 0.80 & 0.10 & 0.82 & 0.08 \\
\hline
\end{tabular}

Table 10. The solar fraction (SF) for the total aggregated load in Uppsala for two weeks in March. The PV integration levels refer to the percentage of suitable areas on roofs and façades for all types of buildings. The charging power was $3.7 \mathrm{~kW}$.

\begin{tabular}{|c|c|c|c|c|c|c|c|c|c|c|}
\hline \multirow{3}{*}{$\begin{array}{c}\text { EV } \\
\text { penetration } \\
\text { level }\end{array}$} & \multicolumn{10}{|c|}{ PV integration level } \\
\hline & \multicolumn{2}{|c|}{$10 \%$} & \multicolumn{2}{|c|}{$25 \%$} & \multicolumn{2}{|c|}{$50 \%$} & \multicolumn{2}{|c|}{$75 \%$} & \multicolumn{2}{|c|}{$100 \%$} \\
\hline & $S F$ & $L F$ & $S F$ & $L F$ & $S F$ & $L F$ & SF & $L F$ & $S F$ & $L F$ \\
\hline $10 \%$ & 0.48 & 0.12 & 0.49 & 0.05 & 0.49 & 0.03 & 0.49 & 0.02 & 0.49 & 0.01 \\
\hline $25 \%$ & 0.44 & 0.28 & 0.48 & 0.12 & 0.49 & 0.06 & 0.49 & 0.04 & 0.49 & 0.03 \\
\hline $50 \%$ & 0.38 & 0.49 & 0.46 & 0.23 & 0.48 & 0.12 & 0.49 & 0.08 & 0.49 & 0.06 \\
\hline $75 \%$ & 0.33 & 0.64 & 0.43 & 0.33 & 0.47 & 0.18 & 0.48 & 0.12 & 0.48 & 0.09 \\
\hline $100 \%$ & 0.29 & 0.75 & 0.41 & 0.42 & 0.46 & 0.23 & 0.47 & 0.16 & 0.48 & 0.12 \\
\hline
\end{tabular}

Table 11. The solar fraction $(S F)$ for the total aggregated load in Uppsala for two weeks in July. The PV integration levels refer to the percentage of suitable areas on roofs and façades for all types of buildings. The charging power was $3.7 \mathrm{~kW}$.

\begin{tabular}{|c|c|c|c|c|c|c|c|c|c|c|}
\hline \multirow{3}{*}{$\begin{array}{c}\text { EV } \\
\text { penetration } \\
\text { level }\end{array}$} & \multicolumn{10}{|c|}{ PV integration level } \\
\hline & \multicolumn{2}{|c|}{$10 \%$} & \multicolumn{2}{|c|}{$25 \%$} & \multicolumn{2}{|c|}{$50 \%$} & \multicolumn{2}{|c|}{$75 \%$} & \multicolumn{2}{|c|}{$100 \%$} \\
\hline & $S F$ & $L F$ & $S F$ & $L F$ & $S F$ & $L F$ & $S F$ & $L F$ & $S F$ & $L F$ \\
\hline $10 \%$ & 0.82 & 0.05 & 0.83 & 0.02 & 0.83 & 0.01 & 0.83 & 0.01 & 0.83 & 0.00 \\
\hline $25 \%$ & 0.80 & 0.12 & 0.82 & 0.05 & 0.82 & 0.02 & 0.83 & 0.02 & 0.83 & 0.01 \\
\hline $50 \%$ & 0.76 & 0.22 & 0.80 & 0.09 & 0.82 & 0.05 & 0.82 & 0.03 & 0.82 & 0.02 \\
\hline $75 \%$ & 0.72 & 0.31 & 0.79 & 0.14 & 0.81 & 0.07 & 0.82 & 0.05 & 0.82 & 0.04 \\
\hline $100 \%$ & 0.67 & 0.39 & 0.78 & 0.18 & 0.80 & 0.09 & 0.81 & 0.06 & 0.82 & 0.05 \\
\hline
\end{tabular}


This is a postprint version of the final paper, which is accepted for publication in Energy: https://doi.org/10.1016/j.energy.2018.11.050

\subsection{Power peaks}

Figure 9 to Figure 12 shows the hourly EV charging load compared to the hourly PV yield for two weeks in March and July in Troms $\varnothing$ and Uppsala. The top graph in each figure shows the EV charging profile (power demand) and the PV yield (available power). Note that both profiles are shown on the positive left $y$-axis in the top graph. The dotted line in the top graph in each figure shows the instantaneous solar fraction $S F(t)$ on the right y-axis. The bottom graph in each figure shows the surplus PV power (shown here as positive), and the unmet charging load (shown here as negative) during the same period. In all of the figures, the simulated EV charging power was $3.7 \mathrm{~kW}$.
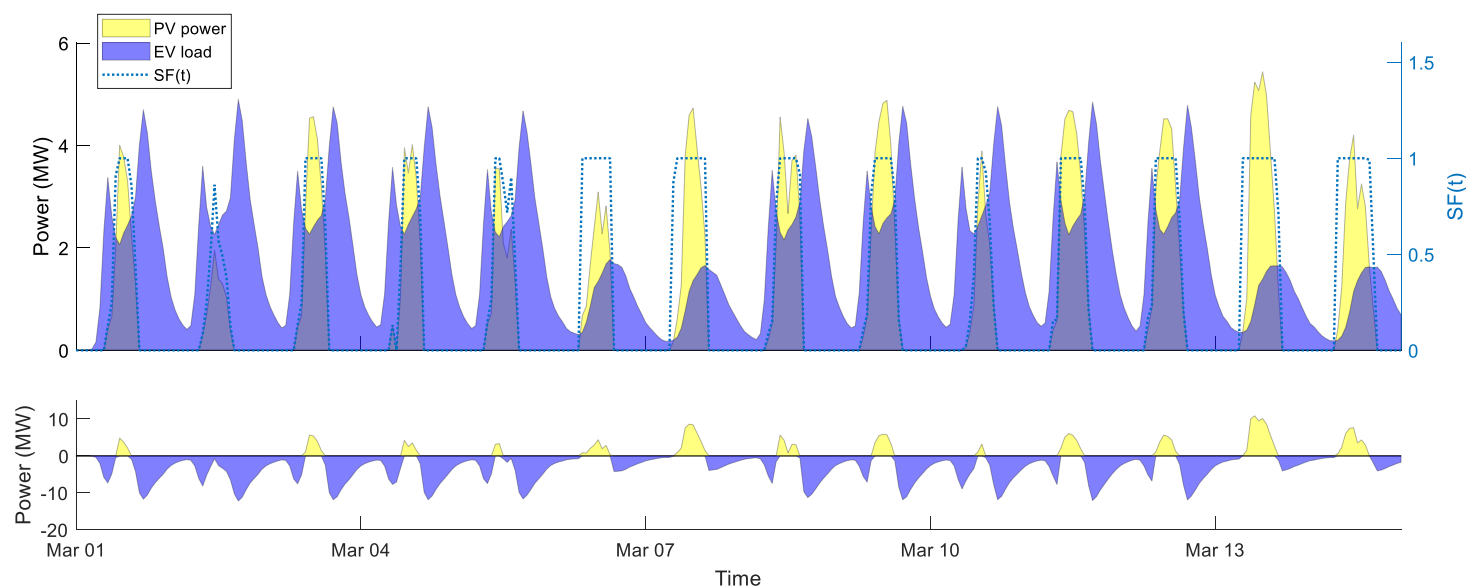

Figure 9. The simulated EV charging load with $50 \% \mathrm{EV}$ penetration and PV power from $10 \%$ of the suitable area on roofs and façades in Tromsø for two weeks in March.
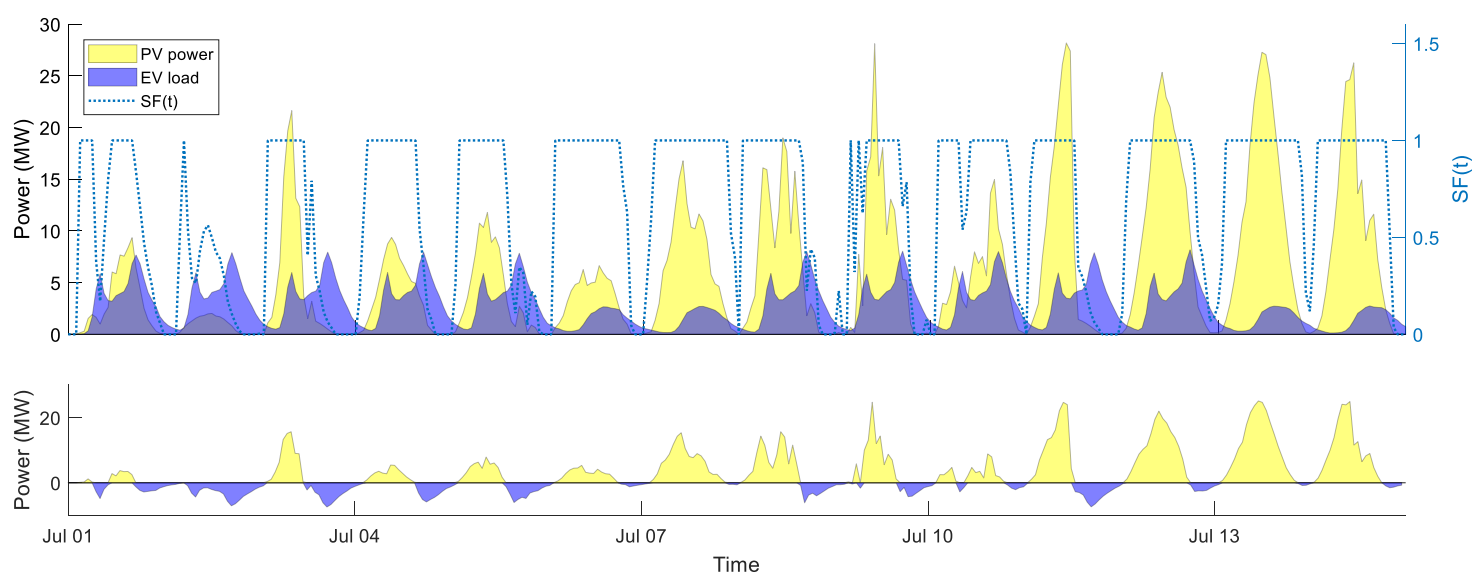

Figure 10. The simulated EV charging load with $50 \% \mathrm{EV}$ penetration and PV power from $10 \%$ of the suitable area on roofs and façades in Tromsø for two weeks in July.

The simulations for Troms $\emptyset$ is shown for the two winter weeks in Figure 9 and for the two summer weeks in Figure 10. The PV power peaks are reduced during both seasons. The EV charging load has two peaks, one during midday and one in the afternoon. Only the midday peak has a significant reduction, since the second peak generally occurs at times with little sunlight, especially during the two winter weeks. The afternoon peak is only reduced on mostly sunny days.

In this scenario, the total PV yield was enough to meet the EV load during summer, but not during winter (Table 8 and Table 9). During the two weeks in March, the highest daily solar energy surplus 
was $59 \mathrm{MWh}$ and the highest daily unmet EV load was $117 \mathrm{MWh}$. The corresponding figures for July were $233 \mathrm{MWh}$ and $65 \mathrm{MWh}$.

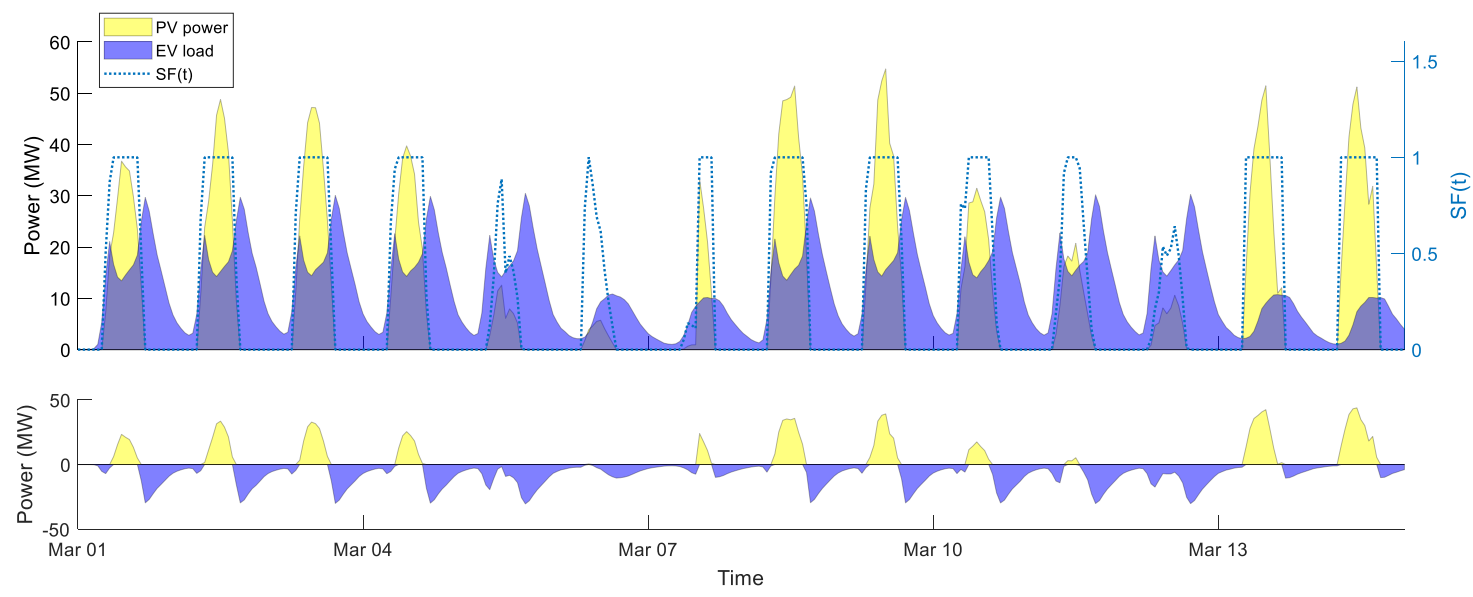

Figure 11. The simulated EV charging load with $50 \%$ EV penetration and PV power from $10 \%$ of the suitable area on roofs and façades in Uppsala for two weeks in March.
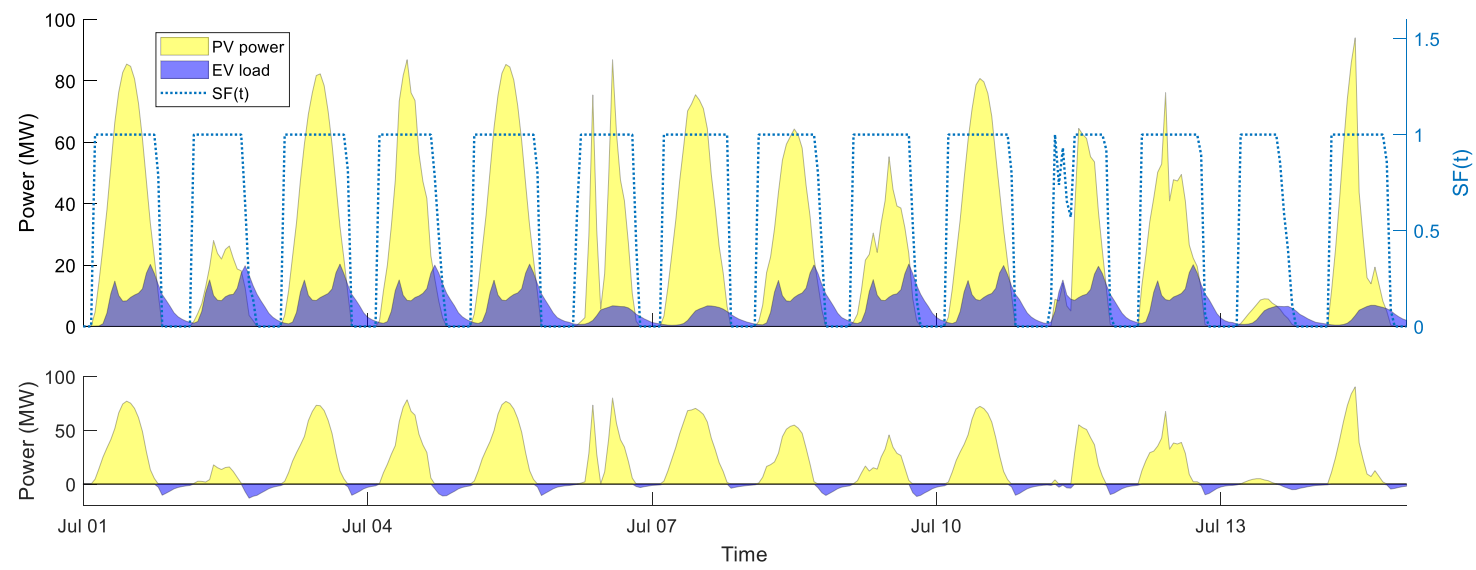

Figure 12. The simulated EV charging load with $50 \% \mathrm{EV}$ penetration and PV power from $10 \%$ of the suitable area on roofs and façades in Uppsala for two weeks in July.

The results for Uppsala shows a similar pattern. The peaks in solar power were reduced, in particular in the summer. For the EV charging, the most significant reduction was in the midday peak, but also in the afternoon peak during summer.

As for Troms $\varnothing$, the total PV yield was enough to meet the EV load during summer but not during winter (Table 10 and Table 11). During the two weeks in March, the highest daily solar energy surplus was $277 \mathrm{MWh}$ and the highest daily unmet EV load was $292 \mathrm{MWh}$. The corresponding figures for July were 694 MWh and 70 MWh.

\section{Discussion}

\subsection{Solar fraction, load fraction and power peaks}

The estimated values of the $S F$ and $L F$ for the aggregated load, given in Table 8 to Table 11, show that there is not a perfect match between solar energy availability and EV charging. However, there is a positive energy balance in most of the scenarios, that is, the total solar energy yield is higher than the 
This is a postprint version of the final paper, which is accepted for publication in Energy: https://doi.org/10.1016/j.energy.2018.11.050

total EV charging load. If the PV integration exceeds $50 \%$ there isa positive net balance for all cases and seasons.

The highest $S F$ values, i.e. high solar coverage of the load, was achieved in Tromsø in the two summer weeks, with values between 0.82 and 0.90 for the lowest EV scenario. This can be explained by the longer days in Troms $\varnothing$ during summer, meaning that there is a higher load match between solar availability and charging load than during winter. For higher EV penetration levels and low PV integration levels, the simulations for Uppsala reach the highest $S F$ values, suggesting that for a certain number of EVs the higher amount of solar energy (due to the higher number of available area in Uppsala compared to Troms $\varnothing$ ) matters more than the shape of the PV yield profile. It is also interesting to note the similarities between the results in Table 8 and Table 10 (winter) andTable 9 and Table 11 (summer), even though the two cities have quite different climate conditions.

The peak PV power was generally reduced when combined with EV charging, while the EV charging load was mostly reduced for the midday peak. Further reduction of the power peaks would be the result of an improved load match, i.e. a higher temporal coincidence between EV charging and PV yield. Increased load match could be achieved if energy storage solutions (residential or industrial) were to be implemented. Use of battery storage could increase the self-sufficiency $(S F)$, since solar energy could be stored to other times of the day. Controlled charging of EVs, for example adjusting the charging power to the available solar radiation, could also improve the direct use of solar power. Battery storage and controlled charging will be the focus of further studies.

\subsection{Limitations and uncertainties}

The estimation of the suitable area on buildings was based on statistical data on building ground floor area combined with rule-of-thumb factors for e.g. shading, obstacles, and unusable areas on roofs and façades. For Uppsala, the building ground floor area was directly available, while in Tromsø it had to be calculated based on the number of buildings and average building areas for different building types. The ground floor area can vary significantly between individual buildings within the same type, especially for non-residential buildings and potentially large buildings such as warehouses. The available areas for solar installations were calculated from the ground floor area (combined with utilization factors). Even though these buildings were generally few in number, they can therefore potentially cause large errors in the roof and façade area estimations.

Another uncertainty is the tilt angle and orientation of buildings. It is difficult to estimate the tilt angle of residential roofs, since this can vary significantly based on the type of building, the year of construction, and even building style of the neighbourhood. A tilt angle of 30 was assumed based on previous studies, for example by [53]. This is lower than optimal for Uppsala as well as Tromsø. More detailed methods are necessary to achieve more accurate estimations of the available area and the solar potential on specific buildings, for example using LiDAR data or image analysis [54, 55].

This study focuses only on solar energy systems on buildings in urban areas. In terms of transportation patterns and solar energy potential, buildings in rural areas might be equally important. In addition, non-building structures in urban areas, such as carports, shading over parking lots, railings etc., might be of interest for solar energy utilization.

The EV simulation method was based on Swedish travel survey data, which were here also used to simulate charging patterns in Norway. There might be differences in the driving patterns in the two 
This is a postprint version of the final paper, which is accepted for publication in Energy: https://doi.org/10.1016/j.energy.2018.11.050

countries that are not taken into account in this study. For example, due to the shorter work hours in Norway, the charging patterns in the afternoon might differ from the Swedish ones.

\section{Conclusions}

The photovoltaic solar energy potential has been evaluated for Troms $\varnothing$ in Northern Norway and Uppsala in Central Sweden, using a method based on building area statistics. The energy yield was estimated for five integration levels of PV in the urban environment: 10\%, 25\%, 50\%, 75\% and 100\% of the solar-architecturally suitable areas on the building roofs and façades.

The energy load due to EV charging was evaluated for the same two locations, using a stochastic model based on travel survey data from Sweden. The charging patterns were simulated for residential, workplace, and other charging for five penetration levels of EVs in the personal vehicle fleet $(10 \%$, $25 \%, 50 \%, 75 \%$ and $100 \%)$.

The PV yield and EV load profiles were compared for all the different scenarios, using the solar fraction $(S F)$ and the load fraction $(L F)$. The values were compared for two weeks in winter (March) and two weeks in summer (July).

The aggregated EV charging load can be covered by the total solar energy yield for most of the scenarios, except some of the scenarios with little PV integration and a high share of EVs in the vehicle fleet during winter. Moreover, if the PV integration exceeded 50\%, the solar yield was enough to meet the charging load of EVs regardless of the EV penetration. The highest solar fractions were achieved for Troms $\varnothing$ during summertime, due to the midnight sun.

The temporal load match between PV yield and EV charging was not perfect. When comparing the power peaks of EV charging and PV yield, it was seen that EV charging reduced the peaks in PV somewhat. In other words, the PV yield was, to some extent, self-consumed by EVs. Of the two EV charging peaks during the day, the earlier one was reduced or removed completely, while the charging peak later in the day was less affected.

Further work will focus on methods and strategies for improving the load match, and thereby the selfsufficiency and self-consumption, for example by the use of battery storage and controlled EV charging.

\section{Acknowledgements}

This project was funded by the EU H2020 ERA-Net Smart Grids Plus project "Increased Self Consumption of Photovoltaic Power for Electric Vehicle Charging in Virtual Networks" [grant numbers 004525-2015 (Sweden) and 259878 (Norway)].

\section{References}

[1] Tran M, Banister D, Bishop J, McCulloch M. Realizing the electric-vehicle revolution 2012. $10.1038 /$ nclimate1429

[2] Huo H, Cai H, Zhang Q, Liu F, He K. Life-cycle assessment of greenhouse gas and air emissions of electric vehicles: A comparison between China and the U.S. Atmospheric Environment.

2015;108:107-16. https://doi.org/10.1016/j.atmosenv.2015.02.073

[3] Ming T, de_Richter R, Liu W, Caillol S. Fighting global warming by climate engineering: Is the Earth radiation management and the solar radiation management any option for fighting climate change? 
This is a postprint version of the final paper, which is accepted for publication in Energy:

https://doi.org/10.1016/j.energy.2018.11.050

Renewable and Sustainable Energy Reviews. 2014;31:792-834.

https://doi.org/10.1016/j.rser.2013.12.032

[4] Olauson J, Ayob MN, Bergkvist M, Carpman N, Castellucci V, Goude A, et al. Net load variability in Nordic countries with a highly or fully renewable power system. Nature Energy. 2016;1:16175.

https://doi.org/10.1038/nenergy.2016.175

[5] Shepero M, Munkhammar J, Widén J, Bishop JDK, Boström T. Modeling of photovoltaic power generation and electric vehicles charging on city-scale: A review. Renewable and Sustainable Energy Reviews. 2018;89:61-71. https://doi.org/10.1016/j.rser.2018.02.034

[6] Grahn P, Alvehag K, Söder L. PHEV Utilization Model Considering Type-of-Trip and Recharging Flexibility. IEEE Transactions on Smart Grid. 2014;5(1):139-48.

https://doi.org/10.1109/TSG.2013.2279022

[7] Grahn P, Munkhammar J, Widén J, Alvehag K, Söder L. PHEV Home-Charging Model Based on Residential Activity Patterns. IEEE Transactions on Power Systems. 2013;28(3):2507-15. https://doi.org/10.1109/TPWRS.2012.2230193

[8] Rolink J, Rehtanz C. Large-Scale Modeling of Grid-Connected Electric Vehicles. IEEE Transactions on Power Delivery. 2013;28(2):894-902. https://do.org/10.1109/TPWRD.2012.2236364

[9] Wang Y, Infield D. Markov Chain Monte Carlo simulation of electric vehicle use for network integration studies. International Journal of Electrical Power \& Energy Systems. 2018;99:85-94. https://doi.org/10.1016/j.ijepes.2018.01.008

[10] Muratori M. Impact of uncoordinated plug-in electric vehicle charging on residential power demand. Nature Energy. 2018;3(3):193-201. https://doi.org/10.1038/s41560-017-0074-z

[11] Mureddu M, Facchini A, Scala A, Caldarelli G, Damiano A. A Complex Network Approach for the Estimation of the Energy Demand of Electric Mobility. Scientific Reports. 2018;8(1):268.

https://doi.org/10.1038/s41598-017-17838-5

[12] Wu C, Wen F, Lou Y, Xin F. Probabilistic load flow analysis of photovoltaic generation system with plug-in electric vehicles. International Journal of Electrical Power \& Energy Systems.

2015;64:1221-8. https://doi.org/10.1016/j.ijepes.2014.09.014

[13] Ruiz-Rodriguez Francisco J, Hernández Jesus C, Jurado F. Voltage behaviour in radial distribution systems under the uncertainties of photovoltaic systems and electric vehicle charging loads.

International Transactions on Electrical Energy Systems. 2017;28(2):e2490.

https://doi.org/10.1002/etep.2490

[14] Ko Y, Jang K, Radke JD. Toward a solar city: Trade-offs between on-site solar energy potential and vehicle energy consumption in San Francisco, California. International Journal of Sustainable Transportation. 2017;11(6):460-70. https://doi.org/10.1080/15568318.2016.1274807

[15] Byrd H, Ho A, Sharp B, Kumar-Nair N. Measuring the solar potential of a city and its implications for energy policy. Energy Policy. 2013;61:944-52. https://doi.org/10.1016/i.enpol.2013.06.042

[16] O'Brien WT, Kennedy CA, Athienitis AK, Kesik TJ. The Relationship between Net Energy Use and the Urban Density of Solar Buildings. Environment and Planning B: Planning and Design.

2010;37(6):1002-21. https://doi.org/10.1068/b36030

[17] Denholm P, Margolis R. Energy Storage Requirements for Achieving 50\% Solar Photovoltaic Energy Penetration in California. Golden, Colorado, USA: National Renewable Energy Laboratory (NREL); 2016.

[18] Statistics Norway (SSB). Over 140000 electric cars in Norway. Online 2018.

https://www.ssb.no/en/transport-og-reiseliv/artikler-og-publikasjoner/over-140-000-electric-cars-innorway

[19] [The Norwegian National Transport Plan 2018-2029] Nasjonal Transportplan 2018-2029.

Melding til Stortinget 2017.

https://www.regjeringen.no/contentassets/7c52fd2938ca42209e4286fe86bb28bd/no/pdfs/stm2016 $\underline{20170033000 d d d p d f s . p d f}$ 
This is a postprint version of the final paper, which is accepted for publication in Energy:

https://doi.org/10.1016/j.energy.2018.11.050

[20] Fridstrøm L, $\varnothing$ stli V. [Vehicle fleet forecasts based on stock-flow modeling] Kjøretøyparkens utvikling og klimagassutslipp - Framskrivinger med modellen BIG. Oslo: Transportøkonomisk Institutt - TØl.

[21] The Government of Sweden. En sammanhållen klimat- och energipolitik - Klimat. 2008.

[22] IEA PVPS. Potential for building integrated photvoltaics 2002.

[23] Number of buildings by building type. Municipalities. 2017. In: (SSB) SN, editor. Private communication: Holst Bloch, Vilni Verner 2017.

[24] Holst Bloch VV. Arealstatistikk fra GAB og FKB Bygg. Datagrunnlag og metode for produksjon av arealtall. Oslo, Norway 2002. https://www.ssb.no/natur-og-miljo/artikler-og-

publikasjoner/arealstatistikk-fra-gab-og-fkb-bygg?fane=om\#content

[25] Good C, Boström T. Analysis of the solar energy potential on buildings in Troms $\varnothing$. Arctic Frontiers. Troms $\varnothing 2018$.

[26] (SCB) SS. Buildings within and outside of localities, number and ground space area, by region by region, type of area, type of property, observations and every fifth year. Statistics Database, scb.se 2017.

http://www.statistikdatabasen.scb.se/pxweb/en/ssd/START MI MI0810 MI0810B/BygglochUta nfTatort/table/tableViewLayout1/?rxid=86abd797-7854-4564-9150-c9b06ae3ab07\#

[27] Photovoltaic Geographical Information System (PVGIS) Ispra, Italy: European Commission, Joint Research Centre, Institute for Energy, Renewable Energy Unit; 1995-2017.

http://re.jrc.ec.europa.eu/pvg tools/en/tools.html\#PVP

[28] Mermoud A. PVsyst. v 6.62 ed. Satigny, Switzerland: PVsyst SA; 2011.

[29] Meteotest. Meteonorm 7. Bern, Switzerland 2017. http://www.meteonorm.com/

[30] Photovoltaic Geographical Information System (PVGIS) Ispra, Italy: European Commission, Joint Research Centre, Institute for Energy, Renewable Energy Unit; 1995-2017.

http://re.jrc.ec.europa.eu/pvgis/apps4/pvest.php\#

[31] Fraunhofer Institute for Solar Energy System (ISE). Photovoltaics report. Freiburg, Germany 2018.

https://www.ise.fraunhofer.de/content/dam/ise/de/documents/publications/studies/PhotovoltaicsReport.pdf

[32] Deutsche Gesellschaft für Sonnenenergie. Planning and Installing Photovoltaic Systems: A Guide for Installers, Architects and Engineers: Earthscan, 2008.

[33] Kanters J, Davidsson H. Mutual shading of PV modules on flat roofs: A parametric study. Energy Procedia. 2014;57:1706-15. 10.1016/j.egypro.2014.10.160

[34] Good CS, Kristjansdottir T, Houlihan Wiberg AAM, Georges L, Hestnes AG. Influence of PV technology and system design on the emission balance of a net zero emission building concept. Solar Energy. 2016;130:89-100. http://dx.doi.org10.1016/i.solener.2016.01.038

[35] Shepero M, Munkhammar J. Modelling charging of electric vehicles using mixture of user behaviours. 1st E- Mobility Integration Symposium. Berlin 2017.

[36] Koralov LB, Sinai YG. Theory of Probability and Random Processes: Springer, 2012. 10.1007/9783-540-68829-7

[37] Neaimeh M, Wardle R, Jenkins AM, Yi J, Hill G, Lyons PF, et al. A probabilistic approach to combining smart meter and electric vehicle charging data to investigate distribution network impacts. Applied Energy. 2015;157:688-98. https://doi.org/10.1016/j.apenergy.2015.01.144 [38] Robinson AP, Blythe PT, Bell MC, Hübner Y, Hill GA. Analysis of electric vehicle driver recharging demand profiles and subsequent impacts on the carbon content of electric vehicle trips. Energy Policy. 2013;61:337-48. https://doi.org/10.1016/i.enpol.2013.05.074

[39] Qi Y, Ishak S. A Hidden Markov Model for short term prediction of traffic conditions on freeways. Transportation Research Part C: Emerging Technologies. 2014;43:95-111.

https://doi.org/10.1016/i.trc.2014.02.007

[40] Swedish Institute for Transport and Communications Analysis, SIKA. RES 2005-2006 The National Travel Survey, Technical Report No. 2007:19. 2007. 
This is a postprint version of the final paper, which is accepted for publication in Energy: https://doi.org/10.1016/j.energy.2018.11.050

[41] Smith WJ. Can EV (electric vehicles) address Ireland's CO2 emissions from transport? Energy. 2010;35(12):4514-21. https://doi.org/10.1016/j.energy.2010.07.029

[42] Salisbury S. Cold Weather On-Road Testing of a 2015 Nissan Leaf. Tech. Rep. June ed 2016. http://avt.inl.gov

[43] Besselink I, Hereijgers J, Van Oorschot P, Nijmeijer H. Evaluation of $20000 \mathrm{~km}$ driven with a battery electric vehicle. Proceedings of the European Battery, Hybrid and Fuel Cell Electric Vehicle Congress. Brussels, Belgium 2011. p. p. 1-10.

[44] Munkhammar J, Widén J, Grahn P, Rydén J. A Bernoulli Distribution Model for Plug-in Electric Vehicle Charging based on Time-use Data for Driving Patterns. IEEE International Electric Vehicle Conference (IEVC), 17-19 Dec 2014, Florence, Italy 2014. 10.1109/IEVC.2014.7056224

[45] Statens Vegvesen. Det sentrale motorvognregisteret.

[46] Trafikanalys. Fordon i län och kommuner 2017, Statistik 2018:3 2018.

[47] Karlsson E, Koch M, Wangenborg S. Electric vehicle charging infrastructure in Uppsala : Current state and potential [Student thesis]2016. http://urn.kb.se/resolve?urn=urn:nbn:se:uu:diva-295031 [48] Skotland CH, Eggum E, Spilde D. [What does the electric vehicle mean for the power grid?] Hva betyr elbilen for strømnettet? In: Skotland CH, editor. NVEs hustrykkeri, Oslo: Norges energi og vassdragsdirektorat, NVE; 2016.

https://www.nve.no/Media/4720/elbil str\%C3\%B8mnett rapport.pdf

[49] Gnann T, Funke S, Jakobsson N, Plötz P, Sprei F, Bennehag A. Fast charging infrastructure for electric vehicles: Today's situation and future needs. Transportation Research Part D: Transport and Environment. 2018;62:314-29. https://doi.org/10.1016/j.trd.2018.03.004

[50] Munkhammar J, Grahn P, Widén J. Quantifying self-consumption of on-site photovoltaic power generation in households with electric vehicle home charging. Solar Energy. 2013;97(Supplement C):208-16. https://doi.org/10.1016/j.solener.2013.08.015

[51] Luthander R, Widén J, Nilsson D, Palm J. Photovoltaic self-consumption in buildings: A review. Applied Energy. 2015;142:80-94. https://doi.org/10.1016/j.apenergy.2014.12.028

[52] Sartori I, Napolitano A, Voss K. Net zero energy buildings: A consistent definition framework. Energy and Buildings. 2012;48:220-32. https://doi.org/10.1016/i.enbuild.2012.01.032

[53] Kjellsson E. Potential for Building Integrated Photovoltaics Study for Sweden - Report 1. Area of Building Envelopes. Lund, Sweden: Department of Building Physics, Lund University; 1999.

[54] Kanters J, Wall M, Kjellsson E. The Solar Map as a Knowledge Base for Solar Energy Use. Energy Procedia. 2014;48:1597-606. http://dx.doi.org/10.1016/j.egypro.2014.02.180

[55] Lingfors D, Bright JM, Engerer NA, Ahlberg J, Killinger S, Widén J. Comparing the capability of low- and high-resolution LiDAR data with application to solar resource assessment, roof type classification and shading analysis. Applied Energy. 2017;205:1216-30.

https://doi.org/10.1016/j.apenergy.2017.08.045 